\title{
The Secret Clergy in Communist Czechoslovakia
}

\author{
FELIX CORLEY
}

Mystery, rumour and scandal have surrounded the question of Catholic clergy ordained in secret during communist rule in Czechoslovakia. Not only were many priests ordained without the required government approval, many (though by no means all) were ordained without the knowledge of the Vatican and, on occasion, against its express wishes. Many were married, and there are reports that some women were ordained.

After the Velvet Revolution of November 1989 brought an end to restrictions on the churches, many of these secret priests came into the open, seeking reintegration into church life. But this was to prove difficult for those ordained in the so-called 'underground church', or the ecclesia silentii as its members preferred to call it.' Those who were married would have the greatest problems.

The first attempt to write in detail on the underground church was the book Bischöfe für den Untergrund by the Austrian Catholic journalist Dr Franz Hummer, ${ }^{2}$ which was published in 1981. Hummer was writing at a time when underground activity was - by definition - illegal and therefore dangerous, and his book had to avoid revealing information about individuals who would be put at risk.

However, with the downfall of the communist regime one of Hummer's colleagues in Austria, Franz Gansrigler, published the book Jeder war ein Papst: Geheimkirchen in Osteuropa ${ }^{3}$ which for the first time revealed a wealth of information about the underground church. Gansrigler concentrated on Bohemia and Moravia, but included shorter contributions on Slovakia, Romania, Ukraine, Hungary and China. This book is important, as it sparked a huge controversy within both Austria and Czechoslovakia. Written from the viewpoint of the aggrieved secret clergy, it praised their activity in the underground and criticised many figures in the official church for alleged compromises with the communist authorities. The book contains an impassioned plea for 'justice': 'The injustice befalling the secret bishops and priests from their church today cries up to heaven.' ${ }^{4}$ Gansrigler claims to have received a verbal nihil obstat from secret bishop Stanislav Krátký just before publication. ${ }^{5}$

The official launch of the book at a press conference in Vienna was a portent of the controversy to come. It featured a heated exchange between secret married bishop Fridolín Zahradník, who strongly defended the validity of his consecration, and Slovak lay Catholic Dr Silvestr Krčméry, who contested it. The spokesman for the Slovak bishops' conference, Fr Fridolin Hlinka, joined Krčméry in the attack. ${ }^{6}$

Condemnation of the book followed from numerous leading Catholic clerics. The most forthright attack was by the Czech primate, Archbishop Miloslav Vlk, who declared it contained 'many untrue and half-true statements' and that it supported 'unhealthy tendencies in the West', doubtless a reference to Gansrigler's apparent support for a married clergy. ${ }^{7}$ Also critical were former secret priests Tomás Halík 
and Miloslav Fiala, both leading figures in the church in Prague.

These critics alluded to numerous 'inaccuracies' (unspecified) in the book, but the main cause of distress was the apparent thesis that, left to itself and without Vatican interference, the local church - in any country - would ordain married men and even women to the priesthood. It is apparently the perceived undermining of clerical celibacy and the attack on church authority that most upset the church hierarchy. 'The book is written on the Austrian model', said Bishop Jaroslav Škarvada. 'In Austria when a bishop appears everyone boos, but they do not believe that here when a bishop appears, everyone claps., 8

In presenting so forcefully the grievances of the underground priests, the book did put the simmering question on the open agenda and - although the Vatican had been concerned about the problem since the late 1960s - it was only after publication in 1991 that the issue was addressed directly by the Vatican and by the church within Czechoslovakia.

The whole question of secret ordinations has affected a number of countries, but has caused the most acute problems in Czechoslovakia. So far, though, there has been no attempt to analyse the question dispassionately. ${ }^{9}$

\section{Secret Ordinations}

There have been numerous cases in the history of the Catholic Church when persecution has driven the church underground. As a church that depends upon a priesthood for three of the seven sacraments (confession, the Mass, anointing of the sick) and on bishops for two (ordination of priests, deacons and bishops as well as, in normal circumstances, confirmation), the continuation of almost all forms of church life is uniquely dependent on clergy. Thorough theological training and valid, canonical ordination preserving apostolic succession are required. As in the communist-ruled countries, previous persecutions have required the ordination of priests in secret, as well as the sending of priests abroad for training and ordination. The survival until well into the twentieth century of seminaries in Rome, Lisbon and Valladolid serving the church in Britain are testimony to previous attempts to get round the ban on open Catholic activity in the British Isles. The Russicum was founded in Rome in 1929 at the instigation of Pope Pius XI to prepare priests for eventual work in Russia. ${ }^{10}$

It was the anti-Catholic persecutions in Mexico in the 1920s that were to provide the model for Czechoslovakia and to which reference is made by those claiming justification for secret ordinations right into the 1980s. The Mexican government prevented all legal church activity. A flavour of the persecution is given by Graham Greene, who visited Mexico in 1938:

In July 1926, Father Miguel Pro... came back to his own country from a foreign seminary much as Campion returned to England from Douai.... Within two months of Pro's landing, President Calles had begun the fiercest persecution of religion anywhere since the reign of Elizabeth. The churches were closed, Mass had to be said secretly in private houses, to administer the Sacraments was a serious offence.... The prisons were filling up, priests were being shot.... They got him, of course, at last. ${ }^{11}$

The first secret consecrations to take place in a communist country were in Russia in 1926 when, with the knowledge and approval of the Vatican, the newly consecrated Michel d'Herbigny consecrated Pie Neveu behind closed doors in Moscow's St Louis 
des Français church. Neveu was not, for the moment, to exercise any episcopal functions. The following month d'Herbigny consecrated two more secret bishops. Pope Pius XI had earlier decided 'to establish at least a provisional hierarchy' to lead the church after the arrests and deportations of the early $1920 \mathrm{~s}^{12}$

These consecrations - partly as a result of d'Herbigny's amateurishness - did not remain secret for long. While d'Herbigny lived the rest of his life in disfavour, if not disgrace, the local bishops came to a sad end. The secret consecrations were universally regarded as a dismal failure. There were few that held them up to be a model for the church to survive the postwar persecutions in newly communist Eastern Europe, China and, later, South East Asia. If there were any lessons to be drawn, the involvement of enthusiastic foreigners on a 'freelance' basis was to be avoided.

But there were some key differences between Russia of the 1920s and 1930s and postwar Eastern Europe, where the Vatican was to undertake further secret consecrations. The Catholic Church was weak and widely dispersed in Russia. Stalin's persecutions were so severe that even strong churches such as the Russian Orthodox barely managed to survive. In Czechoslovakia, on the other hand, the Catholic Church was the biggest national church and, especially in Slovakia, retained the strong loyalty of the people. A similar situation obtained in Western Ukraine, where the Ukrainian Catholic Church was a powerful force in a compact area. In Romania (the Eastern Rite Church) and in China the faithful tended to be concentrated in certain areas, but never in an overwhelming majority.

Although the Vatican permitted consecrations without state approval in Romania and elsewhere in the late 1940s and early 1950s, it was in Czechoslovakia that such consecrations were most widely used.

The history of the Catholic Church has also known numerous occasions where bishops have conducted consecrations and ordinations against the Vatican's wishes, creating schismatic groups. The most famous recent example is that of French Archbishop Marcel Lefèbvre, who founded his Priestly Fraternity of St Pius X in 1970, which eventually led to the establishment of a separate seminary at Ecône in Switzerland without the approval of the Vatican. ${ }^{13}$ Although in many ways the fraternity is at the opposite end of the theological spectrum from underground groups in Czechoslovakia, there are remarkable parallels between Lefèbvre and Czechoslovakia's leading rebel, Felix Davídek.

Because Lefèbvre had been canonically consecrated, his Ecône ordinations were valid in the eyes of the church. However, as he had been expressly forbidden by the Vatican to conduct them, they were not licit. A similar distinction lies at the heart of the dispute over whether the secret church in Czechoslovakia had the authority to ordain and consecrate.

\section{Consecrations in the First Communist Years}

Church-state conflict began soon after the 1948 communist putsch. In the new regime's drive to control and destroy the Catholic Church special emphasis was put on destroying the power of the bishops and priests. Hundreds of clergy were imprisoned, while hundreds more were sent to do forced labour. As state approval would not be forthcoming, the church consecrated five bishops in 1949 and 1950 without state approval (Kajetán Matoušek for Prague, František Tomášek for Olomouc, Štefan Barnaš for Spiš, Ladislav Hlad for Prague and Karel Otčenášek for Hradec Králové). ${ }^{14}$ The church made no attempt to keep these consecrations secret and the state did everything it could to obstruct them. 
Special faculties had been given to Czech bishop Štěpán Trochta of Litoměrice by the Vatican in 1949 to allow the creation of one secret episcopal successor for each diocese in case of the arrest of the bishops. According to the most probable version of events, before his expulsion from Czechoslovakia in 1949 the Vatican's chargé d'affaires in Prague, Mgr Gennaro Verolino, was actively engaged in passing on these faculties. 'Naturally it did not escape the secret police's attention', Stehle reports, 'that Monsignor Verolino, a peripatetic Neapolitan, was travelling around the country visiting the bishops and vesting them with those powers to establish a substitute and underground hierarchy.'15

It seems that with their consecration the new secret bishops received personal episcopal status, which would become effective for diocesan functions only on the arrest of the incumbent bishop. Although documentation on this permission is not available, it seems that each bishop could consecrate one secret bishop, and these bishops in turn could ordain priests without notifying the state or the Vatican, although this second generation of bishops was not empowered to consecrate further bishops. ${ }^{16}$ Church spokesmen claim that these special faculties, given by Pope Pius XII, expired in the mid-1950s, and definitely by the time of Pius XII's death in October 1958. Supporters of the later secret consecrations claim that these faculties were never revoked.

As a result of these faculties, two bishops were consecrated in Slovakia in 1951, Pavol Hnilica SJ and Ján Korec SJ. ${ }^{17}$ In Bratislava on 24 August 1951, recalled Korec,

I was consecrated as a clandestine bishop. Bishop Hnilica had to leave the country and I took up my duties... . The police had known since 1951 that I had been secretly consecrated and that, along with other activities, I was ordaining priests. I had already received the instruction direct from Rome that there should always be two bishops - uno nascosto, uno attivo [one hidden, one active]. ${ }^{18}$

These hasty consecrations were - it seems - acceptable to the Vatican, despite the unusual features of the appointments. Korec, for example, was technically ineligible for episcopal rank: he was only 27 when consecrated, although canon law specified 30 as the minimum age, and he had been a priest for less than a year, rather than the specified minimum of five. ${ }^{19}$ Korec, according to some accounts, later had some difficulty gaining recognition for his consecration from the Vatican.

These underground consecrations - as in Moscow in 1926 - could not be kept secret for long. All were unmasked, Otčenášek in 1950, Hnilica and Korec in 1951. Matoušek escaped unmasking for a while by not exercising his episcopal office. ${ }^{20}$ Otčenášek was arrested in 1950 and spent ten years in prison. Korec was not arrested, for some reason, until 1960 . None of these consecrations was recognised by the state, although some of these bishops, such as Korec and Otčenášek, did receive a state licence in the 1960 s to work as simple parish priests. (Otčenášek also acted as a bishop during the Prague Spring, but not for long.) It was not until the fall of the communist regime in 1989 that the Vatican was able to reappoint those still alive as resident bishops.

After 1948, the new communist regime also had a plan to eliminate the current hierarchy and consecrate new bishops without the Vatican's approval in an attempt to form a national Catholic Church which would be loyal to the regime. A 1950 report from the Office for Religious Affairs to the presidium of the central committee of the Communist Party confirmed 'the elimination of the present hierarchy as a concrete 
short-term aim'.21 There were various suggestions that Catholic bishops from the newly conquered Soviet territories of Lithuania or Latvia could be used to consecrate new bishops and ordain priests in such a regime-loyal church. ${ }^{22}$ This avenue does not appear to have been pursued.

Just six months later, in January 1951, the presidium asked Zdeněk Fierlinger, the newly appointed head of the Office for Religious Affairs, to find out whether any Czechoslovak bishops would be prepared to undertake new consecrations. Interestingly enough, an apparent Vatican order forbidding unapproved consecrations was quoted as the reason preventing such a move. 'Fierlinger reported that secret "decrees" [sic], copies of which they had obtained, forbade the hierarchy expressis verbis to consecrate any new bishops without the consent of the Pope. ${ }^{23}$ It is not clear whether these decrees, if they existed, countermanded the special faculties given to Trochta or whether they specifically banned the consecration of new bishops in a schismatic church loyal to the state.

After the 1949-50 round of consecrations, the Vatican appears to have changed its mind. The difficulty in keeping these consecrations secret perhaps led the official church to the view that this method of preserving the hierarchy was not too successful. The bishop's function is, by definition, public, and any appearance in public would immediately reveal the bishop's identity. Therefore, the Vatican must have concluded, any diocesan leadership would be impossible. The second function of a bishop, administering sacraments (in particular ordination of priests and deacons and consecration of bishops), could be better performed in other ways. Confirmation, in normal circumstances conducted by a bishop, was either neglected or delegated to certain priests.

In addition, parallel consecrations at a time when the church was able to exist legally, albeit under strict state control, caused confusion and doubt among believers. In the case of completely illegal churches, such as the Eastern Rite Church in Ukraine and Romania, for example, or the Vatican-loyal church in China, secret ordinations and consecrations were a necessity and continued much later, although - from the 1970 s at least - with closer control from the Vatican. In Czechoslovakia, the church dispensed with the secret consecrations after the early $1950 \mathrm{~s}$.

Bishop Korec was to exercise his powers of consecration just once in those years: on 9 September 1955 he consecrated Fr Dominik Kal'ata SJ. On 18 May 1961 Kal'ata in his turn consecrated Fr Peter Dubovský SJ in Prague. In 1967 Dubovský consecrated Fr Jan Bláha in Augsburg, and Bláha consecrated Fr Felix Davídek, which led to a proliferation of bishops on a scale that had definitely not been envisaged by the Vatican. Korec was to be the foundation of the Vatican-loyal underground church in Slovakia, drawing in as key co-workers Dr Silvestr Krčméry, Vladimír Jukl and, later, František Mikloško. Whether Korec had authorisation for the 1955 consecration of Kal'ata, who soon emigrated, is unclear, although Korec remained persona grata in the Vatican.

Although Korec continued ordaining priests, he consecrated no more secret bishops after Kal'ata. It is possible Korec was warned off further consecrations by the Vatican. No other Vatican-approved secret bishops consecrated any other bishops in secret. However, a number of further consecrations by Vatican-approved bishops did take place. Cardinal Štěpán Trochta of Litoměřice, who died after an interrogation in 1974, is believed to have consecrated Fr Jindrik Pesek and possibly others. Cardinal František Tomášek is also reported to have conducted a number of consecrations, ${ }^{24}$ as is the Slovak Eastern Rite bishop Vasyl' Hopko, whose church was not able to exist openly until 1968. 
By the time of the Prague Spring, most bishops had decided unilaterally that further secret consecrations were counterproductive. Dubovský - who had been arrested in 1962 after being unmasked and who spent the next six years in prison - told the visiting Stehle in 1968 that a church founded on secret bishops would make sense only if one believed that 'in ten years every thing would be over'. Dubovský went on:

However, even in this case the attempt was more than dubious because the omnipotence of the secret police was underestimated, as was the risk existing for those who had to perform their duties, such as ordaining priests, administering confirmation, without official permission, if they were to fulfil their episcopal function at all.

Dubovský had secretly consecrated Bláha in 1967, but within a year he seems to have changed his mind and told Stehle that such consecrations were ineffective.

Stehle asked Dubovský what instructions he had received from the Vatican to guide him.

Nothing; we were left to ourselves - everyone for himself; most were inexperienced, young, naive, spiritually afire. We had trouble not hating those who were trying to help themselves and the faithful by compromises because they thought that the conditions were permanent and to be accepted as an act of God. From the Holy Father we now and then heard calls that could be interpreted in several ways. ${ }^{25}$

While the Vatican and those secretly consecrated with Vatican approval considered that the unmasking of the secret bishops proved the ineffectiveness of this strategy, this did not deter Bishops Bláha, Davídek and others from later secret consecrations. Obviously Davídek and others were directly inspired by the consecrations of the early communist years, but drew the conclusion that it was the failure to maintain strict secrecy that gave them away. It is here that their model of episcopal office under the changed circumstances of persecution diverged markedly from the Vatican's view. However, they claim Vatican approval for their activity.

According to the Davidek circle, Bláha and Davídek were personally given permission to continue this practice by Pope Paul VI in 1967. Fr Jan Bláha was able to travel to Rome, where he had a personal meeting with the Pope. He informed him about the difficult situation of the church in Bohemia and Moravia and the Pope then reportedly gave permission for the two to be consecrated. 'On the strength of that [Davidek] received his mandate from the Pope, and with this the Pope also directed out work', Davídek's close colleague Ludmila Javorova declared. ${ }^{26}$ This version of events, reported by Gansrigler on the strength of interviews with Javorova and Fr Leo Kuchar (a secret priest from Brno who later sought refuge in Austria), has not been confirmed or denied by Bláha. He has refused to comment. ${ }^{27}$

\section{Bishop Davídek}

Much of the controversy surrounding the underground church centres on the figure of Bishop Felix Maria Davídek, who from 1967 until his death in 1988 was the single most important figure. ${ }^{28}$ During his episcopal career he is said to have ordained hundreds of priests and 'between eights and ten' bishops. ${ }^{29}$ Some describe him as a 'genius', others as mentally unbalanced, a few as both. It is for many people their attitude to this charismatic but controversial figure which determines their attitude to the whole question of the secret clergy.

Felix Davídek was born in Brno in 1921, and completed his grammar school studies 
during the Nazi occupation, despite suffering from severe tuberculosis. He studied during the war at Brno seminary and was ordained priest by Assistant Bishop Stanislav Zela of Olomouc in 1945. He was highly educated, with a love of natural sciences and medicine, as well as poetry, and knew a number of foreign languages, including Latin. Just before ordination he wrote a meditation on the way of the cross, under the pseudonym Václav Ara. The young Fr Davídek 'was chaplain in Horný Stepanov near Boskovice', his former colleague Fr Vladimír Richter reports. 'After the communist putsch [in February 1948] he set up there a kind of underground education for about 20 students whose education had been made impossible by the communists. ${ }^{30}$ Soon after the communist takeover he was transferred by Bishop Karel Skoupý to near Moravský Krumlov, but continued his work with his secret pupils.

Some time around Easter 1950, as pressure increased on Catholic priests, Davídek decided to flee Czechoslovakia. However, news of his plans reached the police. He was already known to the police for his openly anticommunist sermons. He was arrested at the station in Zebetov together with a few of his students. Davídek managed to escape from Boskovice prison in June 1950 and disappeared underground, living with friends. He again planned to flee the country for Vienna, hoping to go on to South America to work as a missionary. He was arrested near Breclav and was sentenced to 25 years in prison. He was sent to various prisons, including a spell at the uranium mine in Jáchymov.

There are many leading figures in the church today - bishops such as Otčenášek, priests such as Oto Mádr and laymen such as Václav Vaško - who remember Davídek from his prison days. By all accounts he did much to keep up the spirits of his fellow prisoners. He was frequently transferred from cell to cell because he continued to say Mass openly, as well as organising theological lectures. Even in prison he thought deeply about the future shape of the church and his role in it after his release. This makes it difficult for those who were imprisoned with him to share the current criticism; or at the least they feel the need to temper criticism with recognition of his work.

While many priests were released from the end of the 1950s, Davídek was not freed until 1963. Unlike some other priests he was not allowed to resume official priestly work so he got a job as a disinfecter in a children's clinic in Brno. It is clear that Davidek was ambitious and openly sought consecration as a bishop. Together with Fr Jan Bláha he approached the Slovak Jesuit Bishop Peter Dubovský (who had been consecrated in secret in 1961), but Dubovský considered him unsuitable for consecration. In 1967 Dubovský consecrated Bláha in Augsburg in West Germany, apparently with the approval of local Bishop Josef Stimpfle. The same year Bláha in turn consecrated Davídek.

It was soon after this that Davídek began ordaining priests and bishops in secret. It was his constant fear that the institutional church would again be wiped out through wholesale arrests - as it had been in Russia in the 1920s and in Czechoslovakia in the early $1950 \mathrm{~s}$. He believed that a wide circle of secret priests would be able to take over the running of the church on conspiratorial lines if the open clergy were all despatched to Siberia. Such prospects may seem far-fetched from today's perspective, but Davídek had had direct experience of just such widespread arrests in Czechoslovakia. He was aware of the secret ordinations conducted in 1950 with Vatican approval.

The Prague Spring brought relaxation in state restrictions on the church, and many previously banned priests were able to resume pastoral work (including Korec, Otčenášek and Dubovský - although not Davídek). The Eastern Rite Church was 
relegalised in Slovakia. Davidek was sceptical about how long these freedoms would last, fears that were confirmed with the Soviet-led invasion of 20-21 August 1968. In the course of a few days, Davidek is said to have consecrated many bishops and ordained hundreds of priests. His consecration of Fr Stanislav Krátký on 27 August 1968 was typical. Davídek informed Krátký a few days before the chosen date that he would consecrate him bishop and gave him the date and time. 'All these consecrations were kept strictly secret', recalled Krátký.

Apart from the witnesses there were no other people present at the consecration. Perhaps there were others in Davídek's house, but I was not concerned with that. I did not look around, did not observe. I knew nothing extra, only as much as was necessary. Thus it was impossible to give anything away if one were unmasked. ${ }^{31}$

Most of Davídek's new clergy were based in his native Moravia, but eventually he had a network that covered the whole of Czechoslovakia. He was constantly travelling to keep in touch with his followers, always overseeing even the smallest details of his flock. Few apart from himself knew more than the bare minimum about his church: Davídek's wariness made him organise the church on a cell system, so that each member knew only a few other people around himself.

One of those he trusted was Ludmila Javorova, a woman who came like Davídek from the village of Chrlice and whose family were friendly with the Davídek family. Javorova was the first person Davídek turned to on release from prison in 1963, and she agreed to gather on his behalf names of young men who wanted to become priests. Javorova has denied that she was ordained by Davídek, but says she did act as his vicar general.

It was in about 1972 that the secret police discovered that Davidek was a bishop possibly from Vatican leaks or from information picked up in Czechoslovakia ${ }^{32}$ and surveillance increased. Both he and Javorova were interrogated. Priests Davidek visited lost their state licences. However, the communist authorities never sentenced Davídek despite being fairly fully informed of his secret work. According to one commentator, Hansjakob Stehle, writing in 1981, the Prague government 'used Davídek's "dissident" church as an instrument to promote distrust and schismatic tendencies in the "official" clergy, to cast doubts on their loyalty and to cause the Vatican to intervene." 33

According to Stehle, ${ }^{34}$ Vatican envoy Fr John Bukovsky spent several hours talking to Davídek in the summer of 1977 during a visit to Czechoslovakia. Davídek and Javorova had just returned from a trip to the Crimea. (Javorova - who opened the door to Bukovsky wearing an episcopal-like cross - claims to have taken a full part in these discussions 'in my capacity as vicar general'. ${ }^{35}$ ) Bukovsky's visit, permitted although closely watched by the communist regime, was aimed at finding a resolution to the question of the vacant dioceses and to sound out priests on their attitude to church-state problems. The Vatican viewpoint that Davidek was 'unbalanced' and deviating from the church line seems to date from this visit. If the 1981 edition of Stehle's book on the Vatican's Ostpolitik was read in Czechoslovakia, that would have given the Prague regime further confirmation - not that they needed it - of Davídek's underground activities.

The fact that Davídek was known as a secret bishop did not prevent the authorities allowing him (together with another secret bishop he had consecrated, Dušan Špiner) to visit Japan in 1982, a visit Davídek much enjoyed as he was fascinated by Eastern religions. 
Davidek's health deteriorated from 1983 as a result of a fall down the stairs at home, from which he never fully recovered. His health was worsened by excessive smoking in later years. He was operated on at home by friendly doctors - he would not entrust himself to a hospital - and although the operation was successful he never fully regained his strength. This did not prevent him from continuing his secret work and saying Mass, even when he could hardly hold the chalice.

According to Gansrigler ${ }^{36}$ it was Davidek's idea to use the Cyril and Methodius celebrations in 1985 as an occasion to revive the faith of the church. He asked Miroslav Richter, who headed a secretly founded secular institute, to begin publishing information about the saints and to start prayer meetings. The Velehrad celebrations in July - attended by well over 100,000 Catholics - were reportedly prepared intensively by Davídek and a group from the Cherubin Order. After the events, Davidek encouraged pilgrimages to sites connected with the lives of the saints as well as visits to sites in Hungary.

As expectations of liberalisation increased with the opening up of the neighbouring Soviet Union from 1987, Davídek set to work on an analysis of church life in Czechoslovakia as a starting point for renewal. By the end of 1987 , he had nearly completed the analysis, which he intended to be shown to Cardinal Tomášek and others, after gaining 30 or 40 signatures from young people. In early 1988, as the 31-point petition for religious freedom started by Moravian Catholic Augustin Navrátil gained momentum (which Davídek believed contained unrealistic demands ${ }^{37}$ ), he released his March Analysis, as it came to be called, in Moravia. There was the understanding that it would be given to Tomášek.

The March Analysis is a forthright condemnation of collaborators with the communists within the church, especially in the pro-government Pacem in Terris movement, and a call for church reform. Gansrigler describes it as the impetus for Tomášek's letter of April 1988, ${ }^{37}$ which apparently quotes from the document. Asked why he spoke up so decisively, Tomášek replied that it was not the petition which by then had gathered more than half a million signatures - but Davídek's Analysis which had inspired him. 'I felt compelled from within,' Gansrigler ${ }^{38}$ quotes Tomášek, 'and felt myself obliged to do it.' The March Analysis was also sent to church representatives in other countries, including Cardinals Groer in Vienna, Kuharić in Zagreb, Gulbinowicz in Wroclaw, Willebrands in Utrecht, Meisner in Berlin, Lubachivsky in Rome - and the Pope. There were apparently no replies.

Davidek died on 16 August 1988 in a Brno hospital. Javorova dressed his body in his vestments in the mortuary. As a final irony of his controversial career, his burial was conducted by Brno's vicar capitular Ludvik Horký ${ }^{39}$ (an ex-Pacem in Terris member) in the village of Turany. Many local people are reported to have attended the funeral.

\section{Davidek on the Priesthood}

More than once Davídek expressed his disapproval of or contempt for the 'official' church, which was allowed to exist under close state supervision. Indeed, his vituperative attacks on individual clergymen - among them Cardinal Tomášek, Ludvík Horký and others - are well known. (This did not prevent him remaining in contact with some priests who worked with state approval.) Less well known are his attacks on other underground groups which left his orbit or remained outside it. He always laid great stress on security within his group, being ultra-cautious in evading state surveillance, despite the fact that the secret police, the $\check{S} \mathrm{tB}$, had been aware of 
his activities as early as 1972 . Those who were incautious or careless were excluded. 'From such people', recalled Javorova, 'Felix cut himself off absolutely.'40

As with so much of Davídek's life, his actions were dictated not just by his character, but also by his carefully thought-out views on the church. His period in prison in the 1950 s and early 1960 s led to a reappraisal of the role of the church. According to fellow prisoners he had plans, even a vision, for the future of the church after his release. It was a constant theme of his that it could not go back to the prewar era. The new church had to adapt to the new conditions in Czechoslovakia - of which he violently disapproved - and change itself to survive. Davidek was apparently horrified when his former rector at the Brno seminary, Bishop Karel Skoupý, was allowed to return to his diocese in 1968 during the Prague Spring and to take up office in a blaze of triumph. Davidek believed he should have returned to his post quietly and without pomp, and would thus have been better able to speak to the new society that had grown up without religion. ${ }^{41}$

Of necessity Davídek formulated a conspiratorial network of Catholics living in small groups and served by secret, uncompromised priests. In order to evade detection, many were chosen from the ranks of those the ŠtB would least suspect to be priests: married men. Zahradník believes Davidek's aim in ordaining married men was not to 'destroy celibacy'. It was, rather, 'a question of necessity'. ${ }^{22}$ Davídek organised secret classes for those he had chosen for ordination, looked after by himself and other priests and lecturers banned from holding pastoral office. Despite his own appreciation of a solid theological training, he considered it secondary to a strong faith and loyalty to his group. There are accusations today that Davídek chose men for ordination at random. According to Dr Oto Mádr, a priest who was imprisoned with Davídek and who retains some respect for his work, "he would just meet somebody in the street and ask him: do you want to be ordained?'43 The number of priests he ordained in the days after the 1968 invasion indicate that he was able to make up his mind about ordination at speed.

Davidek did believe in a sacramental priesthood whose orders were passed on by apostolic succession. This is important to stress as in basic Christian communities in other parts of the world (Holland, Latin America) the role of the priest has been diminished. It was precisely because of his recognition that a priest was needed to conduct most of the sacraments that such a conspiratorial network was established. His respect for the church's canon law and historical traditions - even when he ignored them - is evident. When ordaining married men he was careful to ordain them as bi-ritual priests, but technically for the Eastern Rite, which allows married priests. He knew full well, however, that they would almost never say Mass in the Byzantine rite.

Davidek believed his priests should carry out the work officially licensed priests were unable to do. They should avoid baptisms and weddings, and religious instruction for children, who were allowed such instruction up to the seventh class. They should concentrate on administering the sacraments to the sick and dying in hospital - for which of ficial priests could lose their state licence - organise religious education for teenagers and adults, and train, ordain and consecrate new clergy.

Authority in the movement remained largely with himself, or with those he chose to represent him, such as Fridolín Zahradnik, later to be ordained as one of the married priests, or Ludmila Javorova. Davídek could be decisive and harsh with those he disagreed with, excluding them ruthlessly from further contact with himself or his followers.

In most cases it seems that Davidek chose the candidates for the priesthood. 
However, those coming to him who wanted to become priests were strongly discouraged from entering the two official seminaries permitted by the communists, Litoměrice and Bratislava. His suspicion of the seminaries - riddled, he believed, with ŠtB agents - was well justified, and widely shared outside his group. His distance from priests working with state licences was also well known, although he maintained contact and worked together with some. Clergy were forced to hold regular meetings with officials of the State Secretariat for Church Affairs, which in the 1980s set up a special department for work with the Catholic Church, as well as with the secret police. After the 1989 'Velvet Revolution' it was revealed that about 11.5 per cent of the Catholic clergy had collaborated with the StB. ${ }^{44}$

Occasionally in the early days, on request from the heads of the illegal religious orders, Davídek would ordain young men they had chosen. All these priests were celibate, and would experience no difficulty in reintegration into the church after 1989. But they too would be subject to conditional reordination. In 1968 a group of ten Jesuits, some ordained as priests by Davídek, fled to Austria. Bishop Paul Rusch gave them conditional reordination, 'quietly' according to Fr Vladimír Richter, in Innsbruck..$^{45}$ As the official church and the religious orders developed their underground training they later distanced themselves from Davídek and chose bishops from other countries to conduct ordinations instead.

It is known that in 1970 Davidek began actively considering the idea of ordaining women to the priesthood. He is reported by Slovak Catholic layman František Mikloško to have lectured to a group of underground priests and bishops on the topic. ${ }^{46}$ Just as in the case of married men it seems the idea was prompted as much by theological investigation as necessity. In both instances Davidek did not lightly overturn centuries of tradition. However, despite thinking about it Davidek is believed never to have ordained any women, although evidence on this subject is contradictory. Václav Vaško, who was imprisoned with Davídek from 1956 to 1960 , was told by Davidek in Brno in 1981 that he had not ordained any. ${ }^{47}$ Fridolín Zahradník, secretly consecrated in 1970 , replied to a question about female ordinations: 'But not by me and not by Davídek' ${ }^{48}$ Javorova has given contradictory statements on the subject. She told Gansrigler: 'And if there are supposed to be women who claim to be priests or deacons, they could not have been ordained by Davidek. I know. It could have been someone else who ordained them. ${ }^{49}$ However, in 1992 she refused to confirm or deny to a visiting journalist whether Davídek had ordained women or not. 'The time is not ripe to talk about that,' she said. ${ }^{50}$

Davídek, while ordaining married men in the Eastern Rite, insisted on the celibacy of celibate priests. Once a priest had pledged himself to celibacy, he was to stick to it. Married priests who were widowed, as in the Orthodox and Eastern Rite Churches, could not remarry.

\section{Davidek and the Vatican}

Davidek began his episcopal ministry at a time when contacts between the Czechoslovak church and the Vatican were at a minimum. The almost total lack of resident bishops, as well as the absence of diplomatic relations between the Czechoslovak state and the Vatican, gave few direct channels for communication. However, by the time of Davidek's consecration in 1967, the church in Czechoslovakia was by no means as isolated as Davidek and other underground groups maintained. The Prague Spring, brief as it was, allowed freer travel and the resumption of international contact. 
Despite his professed loyalty to the church, Davídek's willingness to listen to the Vatican depended on what message it was sending. Within a year of Davídek's secret consecration, the Vatican had already decided to warn Davidek about his unauthorised activities. According to František Mikloško, a close colleague of Bishop Korec in the Slovak underground church, the Pope passed on a message via Korec. Korec, who had been freed from prison in early 1968 , was in hospital with tuberculosis. He was visited there by, among others, 'secret bishop Felix Davídek together with the secret priest and member of a religious order Ing. Premysl Coufal. At the time Korec gave Davídek the order from Rome to live as a priest and in no way to act from the position of episcopal consecration.' ${ }^{\prime 1}$ Mikloško must have heard this from Korec himself. Davídek died in 1988 and Fr Coufal was murdered by the ŠtB in 1981, so Korec is the only witness for this. Gansrigler claims - improbably - that it could have been 'clerical jealousy' on the part of Korec that the Jesuits had not been involved in his consecration that turned him against Davidek. In any case this meeting seemed to have turned the two into enemies, and they rarely met after this. A later campaign of what Davidek's circle call 'disinformation' about him and Zahradník emanated from within Korec's circle. Until then, Davídek had apparently kept Korec and Silvestr Krčméry, another key figure in the Slovak underground church, informed of his activities. 52

By the early 1970 s the Vatican was already seriously concerned at Davidek's secret ordinations, which, it believed, were getting out of control. In 1972 - at about the time the ŚtB discovered that Davídek was a secret bishop - the Vatican wrote to Davidek ${ }^{53}$ asking him to cease further ordinations without Vatican permission. This was at least a tacit recognition of the validity of his consecration, even if the exercise of that office was a cause for concern. Davidek ignored the instruction.

Fr Bukovsky's 1977 visit was a direct attempt to resolve the problem, as the Vatican saw it, of both the open and secret episcopate. But the visit and its aftermath must have confirmed in Davidek's mind the rottenness of the Vatican's Ostpolitik. The desire to appoint bishops who would be under the thumb of the authorities was, he believed, tantamount to a betrayal of the heroic clergy and a capitulation before state repression. The Vatican's attempts to curtail secret ordinations, especially by himself, was further evidence of communist control over the church. He was convinced no secrets were safe in the Vatican - a view that was at least partly justified. Davídek was already well known for his contempt for Vatican officials involved in the Ostpolitik (he called the secretary of state 'Casaroli the communist'). ${ }^{54}$

He was therefore overjoyed when the Archbishop of Kraków, Karol Wojtyla, was elected Pope in 1978. 'At last we have a Pope', he is quoted as saying, 'who understands how we live under communism. '55 He retained a great respect for Pope John Paul, in contrast with his low view of other Vatican clerics.

Davidek's ambiguous attitude to the Vatican did not prevent him sending detailed descriptions of his work - 'in polished Latin's6 - to Rome. Astonishingly, given Davídek's extreme caution, they were sent through the open post. ${ }^{57}$

After Tomášek's 1987 ad limina visit to the Vatican (which he had to undertake alone - a sign of the government's decimation of the episcopate), the cardinal issued another plea for secret ordinations and consecrations to stop. This - as in the past fell on deaf ears as far as Davídek and others were concerned.

Davidek's low opinion of Tomášek is well known, and few expected him to heed the words of an official cleric he despised, one morover who had been installed in office with government approval. However, Davidek's loyalty to the Vatican can also be questioned. He accepted the Vatican's theoretical jurisdiction over the church in 
Czechoslovakia, yet in practice ignored all instructions issued specifically to him. ${ }^{58}$ His rejection was not based on theological traditionalism - on the contrary, Davidek was in most respects a theological progressive and welcomed the reforms of the Second Vatican Council. But in theology, as in questions of jurisdiction, Davídek set himself up as his own arbiter, who felt no need to refer his decisions to anyone else. The Vatican was right to conclude eventually that he was in effect cutting himself off from the Universal Church and creating his own schismatic group which rejected papal authority. Thus his ordinations, while being valid, were not licit.

\section{Bishop Fridolń Zahradník and Biritualism}

Although there are a number of married secret bishops - Fiala put the number at eight ${ }^{59}$ - Fridolín Zahradník has become the most prominent. He was extensively interviewed by Gansrigler for his book, and unlike many other secret clergymen he has not been shy about talking to journalists. His popularity in the official church was not helped by his appearance at the press conference in Vienna to launch Gansrigler's book.

Zahradník was born on 16 September 1935 in Chrudim and was brought up in a religious home, becoming an altar server when he was five. He studied from the age of 12 with the Salesians in Prague, where he began a long acquaintance with the Salesian Cardinal Štěpán Trochta, remaining in contact with him until his death in 1974. Zahradník at one time wanted to be a foreign missionary. Despite having the right qualifications, he was barred by the communists from studying medicine. Working in east Bohemia he started a Catholic study group. At the beginning of the 1960 s the group began to copy and study Pope John XXIII's 1961 encyclical Mater et magistra illegally.

The secret police were soon investigating them, however, apparently after they were betrayed by a Pacem in Terris priest. Zahradnik was sacked from his medical work and had to get a manual job. Eventually he was employed as a roofer, rising to head a building firm after 1968 . He specialised particularly in restoring church towers.

Zahradník worked closely with Bishop Davídek as his vicar general, travelling all over the country with him in the late 1960 s. He was ordained priest in 1969 after he says - 20 years of private study. Davídek chose Zahradník to be a priest as he was married. Although the ordination therefore had to take place in the Eastern Rite to get round the law on celibacy in the western church, Davidek believed he would be less obvious to the S̆B as a married man. Zahradník, although familiar with the Eastern Rite, has always said Mass in the Latin Rite.

Zahradnik claims that Davidek had special licence from the Vatican which enabled a transfer from the Latin to the Eastern Rite. ${ }^{60} \mathrm{He}$ also claims that Ján Hirka, apostolic administrator of the Eastern Rite diocese of Prešov from 1969, was given similar powers and passed these on to Zahradník and his group, a claim vigorously denied by Dr Silvestr Krčméry. ${ }^{61}$

However, it is Zahradník's secret consecration as bishop that is the most controversial, as even in the Eastern Rite married bishops are not allowed. He was consecrated in 1970 by secret Eastern Rite bishop Krett, who was himself married and came from the Prešov diocese. ${ }^{62}$ It is he who is also rumoured to have ordained several women. It was apparently the question of ordaining women and married men which finally severed relations between the Korec circle in Slovakia and Zahradník's group. According to evidence gathered by Gansrigler ${ }^{63}$ the Korec group deliberately planted information about Davídek's and Zahradník's activities in the hands of Fr 
Anton Hlinka SDB, a Munich-based Slovak priest who broadcast regularly on the American-funded station Radio Free Europe. They allegedly believed that publicising Zahradník's activities would lead to his arrest, thus taking him out of circulation.

Zahradnik was arrested in late 1983, together with two priests he had ordained, Milan Beran, who was married, and Václav Netuka, who was celibate. The three were interrogated for nearly a year, apparently to make them confess to being 'agents of the Vatican'. However, it was clear that Hlinka's revelations were nothing new to the secret police. They had known since 1977 that he was a secret bishop. 'Zahradnik reported', declares Gansrigler, 'that the secret police said during the interrogations that they were no longer interested in the secret church, but had to take some action after the RFE broadcasts - apparently on the direction of the interior ministry., 64

Zahradnik and his colleagues were finally tried in March 1987 for alleged theft of building materials and received long prison sentences. ${ }^{65}$ The influence of the Korec group and the loyal underground church is shown by the fact that the respected Prague-based Committee for the Defence of the Unjustly Prosecuted (VONS), an offshoot of Charter 77, did not take up their case until 3 February $1988,{ }^{66}$ long after their original trial. Even then VONS did not question the essence of the case, merely declaring that 'political factors' had caused the long sentences to be handed down.

\section{Underground Circles}

Gansrigler names twelve secret bishops: Jan Bláha, Felix Davídek (died 1988), Jindrik Pesek (died 1980), Fridolín Zahradník (Eastern Rite, married), Jiři Krpalek, Bedřich Provaznik, Václav Razík (died), Oskár Formánek SJ (died 1991), Eugen Kocis, Dušan Špiner, Stanislav Krátký and Krett (Eastern Rite, married, died). Gansrigler also names Jan Jiři Pojar, apparently consecrated by Davídek, who emigrated in 1970 , and who never exercised his episcopal functions. He is now married and lives in Zurich.

Although Davídek's was not the only underground group, it was by far the most influential. His views carried weight not only in his own circle but throughout the underground church. Although he believed in strict loyalty and liked his followers to cut themselves off from the open church and other underground groups, there were many believers, both clerics and laymen, who were active in the different parts of the church. This crossover brought a two-way flow of ideas and a sharing of experience, although Davidek himself was not open to ideas from outside sources.

His thinking on women priests became widely known, particularly in Slovakia, although with opposite reactions. One group, led by Bishop Krett, was prepared to accept women priests. The other, centred on Bishops Korec and Dubovský, distanced itself from Davidek when he started thinking in ways that broke church law. The fact that members of underground circles describe suggestions that such and such a bishop ordained women as attempts to 'discredit' them ${ }^{67}$ implies that most such groups did reject women's ordination to the priesthood both in theory and in practice. Zahradnik would, however, be prepared to contemplate women deacons. ${ }^{68}$

Krett was consecrated in the Eastern Rite church in Slovakia either by Davídek (who knew the Eastern Rite well) or by Vasyl' Hopko, assistant bishop of Prešov. According to Slovak layman František Mikloško, who became president of the Slovak parliament after 1989 , Krett ordained at least two women in Slovakia. ${ }^{69}$ In the 1980s several women are reported to have come to Cardinal Tomášek, worried about the validity of their ordinations. He told them that women cannot be priests and that if they were still acting as priests they should stop. Secret bishop Krátký believed 
the StB could have encouraged the ordination of women 'to damage us' or have provided imposter bishops to make such 'ordinations' ${ }^{70}$ (There are rumours that nuns were ordained as priests after the herding of female religious into 'concentration convents' in the $1950 \mathrm{~s}$, to enable them to continue receiving the sacraments when priests could not gain access, but there is no proof of this. Bláha told Gansrigler it could well have happened, while Zahradník denied it to Gansrigler. ${ }^{71}$ )

This concern about ordinations was also shared by a number of priests of the underground church worried about whether their ordinations were valid. As travel became easier in the 1980 s, a number came to Austria to seek advice and possible conditional reordination from Austrian bishops. Without proof of their identity or documents attesting to their ordination, the bishops concerned referred the matter to the Vatican for advice. They were apparently told from Rome not to proceed with reordination, to advise the priests to stop celebrating Mass and to await a change of regime in Czechoslovakia which would - the Vatican hoped - allow the matter to be resolved. ${ }^{72}$

In addition to those who sought advice from the official church, both within and outside Czechoslovakia, there are those ordained secretly who decided themselves not to practise as priests. Gansrigler mentions numerous examples of priests 'who wanted to have nothing to do with their ordination' ('von seinem Ordination nichts wissen wollten').

The official church has, since 1989 , made much of the worries entailed by these secret ordinations, not just to those ordained, but to those receiving the sacraments from them. Not only were priests worried as to whether the Masses they said were valid, lay people were worried about the validity of the sacraments they had received.

The decision by Davidek to ordain married men, followed by other parts of the underground church, seems to have lifted the bar on priests who had subsequently married from continuing their pastoral work in underground circles (although this would not have been acceptable to Davídek). One priest from České Budéjovice diocese, who lost his state licence after the 1968 Soviet-led invasion, later married and was thus barred from continuing to function as a Vatican-loyal priest. As a priest he had been active in religious work with scouts and other young people's groups, but this had to cease when he lost his licence. However, one part of the underground church continued to accept him as a priest, and he administered the sacraments in this group. ${ }^{73}$

The vast majority of secretly ordained priests - numbering several hundred carried out their vocation as priests (as they and their bishops saw it) faithfully and conscientiously. The commentator Václav Němec reports that of the underground priests who came forward after 1989 , 'the majority are educated men' ${ }^{74}$ One reason for this may have been that the highly educated, who might have made a good impression as priests, were more likely to be refused admittance to the official seminaries by the State Secretariat for Church Affairs. The secret priests often had to combine two or, if they were married, three occupations at once: their priesthood, their job and their family. Zahradník argues that it was easier for priests who were married to endure imprisonment than for those who were not. 'A celibate priest was alone in jail with God. I was there with God and with my family's love. ${ }^{75}$

The secret police constantly tried to infiltrate these underground circles and discover the names of bishops and priests. This was done through surveillance, interrogation and infiltration. ${ }^{76}$ In extreme cases the $\breve{S t B}$ resorted to murdering priests, including the Benedictine Fr Premysl Coufal. Because of this, many secret priests did not even tell members of their own families that they had been ordained. 
There were many parents of secret priests who were surprised after 1989 to discover the role their sons had played in the underground church. Occasionally, though not usually, some wives of married priests did not even know their husbands had been ordained. Other priests involved their families. 'My wife and I have five children,' said Fr Praža. 'I needed her permission to become a priest. I was ordained at home in my family's presence.'77

The official clergy with state licences sometimes played their part in betraying secret priests. Zahradnik and his group first got into trouble after a Pacem in Terris group informed on them. Fear, a desire to curry favour or suspicion of the activities of underground priests led to such betrayals.

Suspicion of the clergy with state licences was mirrored by suspicion of the Vatican which, many believed, had been penetrated by communist agents. 'One secretlyordained bishop told me in the funeral procession of an outstanding Catholic lay activist', Fr František Lizna recalled, 'that they had had such bad experiences that they sometimes did not report secret ordinations to Rome: it would happen that the secret police would hear about them whenever they were reported' ${ }^{78}$

Underground circles also sought to help the church in the neighbouring Soviet Union where, they believed, it was even more persecuted than in Czechoslovakia. Perhaps they also believed that it was as an 'underground' church, with a network of secretly ordained priests, that the church could best witness there as well.

Various projects were begun to supply Bibles and other Christian books, pastoral help and other support. While this was not unique - much help was forthcoming from Poland, as well as from western Catholics - Czechoslovak help was significant. The unique contribution, though, was the ordination of married men to the priesthood. In 1981 a Polish professor at Lublin's Catholic university, Zdisław Hlewyński, arranged for Moscow Catholic convert Vladimir Nikiforov - who was married - to be ordained in Slovakia by secret bishop Dušan Špiner, who had been consecrated by Davídek in 1979. The ordination had been switched from Poland, because Soviet citizens had great difficulty travelling there during the year of Solidarity unrest. This was the first time Nikiforov had met Špiner or, he claims, ever travelled to Slovakia. The short ordination ceremony took place in the Latin Rite, although he was ordained as a biritual priest. ${ }^{79}$

Špiner travelled to Moscow in the following year to ordain another priest, Sergei Nikolenko. He too was married. Silvestr Krčméry claims Špiner consecrated three secret bishops in the Soviet Union, ${ }^{80}$ but details of this are unknown.

Nikiforov was later unmasked, and detained by the Soviet authorities for a few days in February 1983. He was arrested again the following May, but released eight months later without being tried after giving information on other Christian activists. Among other information he gave the KGB, according to Sergei Lezov, writing in Moscow in 1986, Nikiforov 'named the bishop who had ordained him' ${ }^{81}$ After his arrest, Catholics in Czechoslovakia involved in helping Catholics in Russia were interrogated, including Dr Silvestr Krčméry in Bratislava and a woman in Prague. ${ }^{82}$ Presumably the KGB had shared their now extensive information with the StB, with whom they had close ties. ${ }^{83}$

A 1987 article in the Soviet press by N. Yakovlev - apparently based on what Nikiforov had revealed - accused the Vatican of trying to set up a secret underground church in Russia using priests, such as Nikiforov, illegally ordained in Czechoslovakia. ${ }^{84}$ 'At the invitation of a certain V. Rosik,' Yakovlev wrote, 'Nikiforov travelled to Czechoslovakia. On 22 April 1981 in the small village of Bely Potok, not far from the town of Ružomberok, the illegal Catholic bishop D. Špiner ordained 
Nikiforov as a priest.' Yakovlev maintains he was given the role of vicar general. 'In April 1982,' he continued,

the illegal bishop from the ČSSR, D. S̆piner, conferred orders as a Catholic priest on... S. S. Nikolenko.... The Moscow secret community retained warm relations with the illegal Catholic Church in the ČSSR.... Under various pretexts, illegal Catholic priests from Slovakia R. Fiba, D. Kraiovich, I. Dravetsky, the nuns M. Mastigutova, S. Korbasheva travelled to the Soviet Union with 'gifts' for the community - religious propaganda literature. Enticed by sweet words from the visitors about the greater possibilities of a 'religious revival' in the ČSSR, Nikiforov encouraged visits to fellow believers there by members of his community.

Interestingly enough, Yakovlev picks up on the point, ignored by journalists appointed to attack the secret church in Czechoslovakia, that Nikiforov was married, not normally allowed in the western church. He claims that Polish Cardinal Stefan Wyszyński was prepared to 'turn a blind eye' to this.

Nikiforov emigrated from the Soviet Union with his wife in 1988 and later worked as a priest - with official church permission - in Sweden. Nikolenko remained in Russia and after the relegalisation of the Ukrainian Catholic Church in 1989 went over and worked for them as a priest.

Gansrigler claims the Czechoslovak church also had a Hungarian connection. He declares that of the two 'secret bishops' in Hungary, Gyula Parádi and József Rédei, one - Parádi - was secretly consecrated by an (unnamed) underground bishop from Czechoslovakia. Both Parádi and Rédei, working as parish priests, refused to comment to Gansrigler. 85

\section{The Church's Secret Ordinations}

In Slovakia Bishop Korec, together with his trusted colleagues, Krčméry and Mikloško, was able to develop a network of underground groups that remained loyal to the Vatican. Korec conducted ordinations ${ }^{86}$ - but no further consecrations after 1955 - after proper theological training in secret.

According to the current bishop of Prešov, Ján Hirka, the Slovak Eastern Rite Church had three underground bishops. One has died and two are working as parish priests.$^{87}$ None was consecrated by Hirka, who became a bishop only in $1989-$ his 1969 appointment as ordinary of the diocese did not confer on him episcopal status. The two who are still alive were consecrated by a Latin Rite bishop, the third probably by Vasyl' Hopko, assistant bishop of Prešov who died in $1976 .{ }^{88}$

At the same time that Davidek and others were ordaining their priests in the Czech Lands, the official church there developed its own underground system of training and ordaining priests. Much of the inspiration for and organisation of this clandestine training came from the two theologians Fr Josef Zvěrina and Fr Oto Mádr. Both were of the prewar generation (Zvěrina was born in 1913, Mádr in 1917), and both had been imprisoned by the communist regime. Together they organised the selection of candidates for the priesthood, their training and their eventual ordination. Both had, perhaps not incidentally, been involved in the secret groups set up in Prague after the Second World War by the Croatian-born Jesuit Fr Tomislav Kolakovič (who had also been active in Slovakia). He had devised a method of sustaining Christian community under communist rule by means of what was, in some respects, a foretaste of the teachings of the Second Vatican Council. ${ }^{89}$ 
Ordinations usually took place abroad by trusted bishops. Travel restrictions for Czechoslovak citizens meant that neighbouring communist countries were the usual destination. Among those conducting such ordinations were Bishop Joachim Meisner of (East) Berlin and Archbishop Karol Wojtyla of Kraków. ${ }^{90}$ Wojtyła had a concern for the church in other Eastern European countries, particularly in Czechoslovakia. On 28 October 1979, a year after he had been elected Pope, he described Czechoslovakia as 'a country which is especially close to my heart'. He helped not just with ordinations but with the provision of religious aid. He was always eager to meet and encourage visitors from Czechoslovakia. After meeting Wojtyla in Kraków in 1973, Silvestr Krčméry is reported to have said on his return to Slovakia, 'If only he were Pope!' On hearing on Vatican radio of Wojtyla's election as Pope John Paul II in 1978, Vladimír Jukl exclaimed, 'Just imagine what this will mean for us!'91

Wojtyla was less involved with Belorussia and other parts of the Soviet Union, whose priests were usually ordained by other Polish bishops, but under a similar system. These men would have arrived in Poland with personal recommendation from one of the three vicars general in Belorussia that they were suitable for ordination. In 1987, five of the Belorussian priests working with state approval had been ordained 'privately' in Poland, three in Latvia and four in Lithuania. ${ }^{92}$ (Despite Soviet attempts to wipe out the church in Belorussia, no secret consecrations of bishops took place there.)

Likewise, the men sent for ordination from Czechoslovakia would have had the prior approval of the official church, not just from Zvěrina or Mádr, influential though they were. Once back, the new priests would, while remaining under church discipline, keep their ordinations secret as far as possible from the state.

For a long time the role of Wojtyla in these ordinations was not discussed widely, especially after he became Pope, perhaps for fear of upsetting the Vatican's relations with communist states. It was no secret, but it was only after the communist regimes were overthrown that the topic emerged in print. In a leading article in the Czech church paper Katolický týdenik Fr Václav Maly thanked the Pope for the 'many priests from Czechoslovakia' he had secretly ordained 'so that they could serve their church'.

In addition to ordinations from the Zverrina/Mádr circle, religious orders maintained their own system of recruitment, training and ordination, despite the breaking up of their communities in 1950 . Since they formed more tightly-knit groups than the diocesan priests, and had a stronger system of internal discipline, it was easier for them to organise such training and ordination, likewise mostly abroad. Some, such as the Dominican Jaroslav Dominik Duka or the Jesuit František Lízna, even studied in the official seminaries of Litoměrice or Bratislava and were openly ordained. Others, especially in the years after 1967, were trained in secret within their order but ordained by Bishop Davídek. This method, however, seems to have been short-lived and later the orders kept their distance from Davidek.

With such church-approved methods of evading state controls on ordination, the of ficial church claims that there was never a need to resort to the unofficial secret ordinations as practised in the Davidek and other circles..$^{93}$

Despite the distance between the two groups, there were many priests from the Zverrina circle who had links with the Davídek and other groups. For example, František Lízna was first inspired to become a priest after attending talks and retreats given by Davidek in his native Moravia. He was very much impressed by Davídek's spirituality and vision for the church. However, he joined the state-controlled Litomerrice seminary and after that had no direct contact with the Davídek circle, 
although he had no theological objection to participating in its activities. Fr Lízna for one is unwilling to criticise the activity of Davídek and his colleagues: 'If I had to make a judgment, I would never attack these secret ordinations, either in public or in private. ${ }^{94}$

Likewise, it is notable that at major church events, priests from all three sections of the church - the official clergy, the church's secret priests and priests from Davídek's circles - would come together in public.

\section{The Underground Church and Theology}

Although a gulf divided the underground priests ordained with Vatican approval from those ordained without it, the two groups had much in common. Both of necessity worked closely with the people in small groups, and this broke down the old divide between the clergy and the laity. This is one aspect of the communist-era church that most of these priests would like to retain in some form, even though there is no longer any restriction on parish work.

Priests from both groups express their support for the reforms of the Second Vatican Council, and dissociate themselves completely from any traditionalist, Lefèbvre-style movement. They stress that Lefèbvrism was never strong in Czechoslovakia, although there was one priest in Prague and one in Moravia (both with a state licence) who were allowed by the church to continue saying the Tridentine Mass in their churches. On the contrary, underground priests tended to favour more informal liturgies, usually without vestments. The enforced setting - private flats or outside in the country - added to the informality.

Of necessity, the priest's work in the underground had to be combined with a secular job. Thus they had - on the surface at least - much in common with the worker-priests who developed as a movement in France and Belgium after the Second World War. ${ }^{95}$ A key role in France was played by Fr Henri Perrin and the Mission de France: he formed the thinking that backed up this new pastoral approach. Like the underground clergy in Czechoslovakia, the worker-priests believed that the new industrial working class had grown so far from the traditional church that a new approach to pastoral ministry was needed in order to reduce the distance between priest and people. This involved taking industrial jobs, such as in car factories, and ministering to the people in off-duty hours. However, the Vatican soon became concerned that such priests were getting involved in militant trade union activity that was sidetracking them from their vocation as priests. The movement was curtailed in 1953-4, and suppressed in 1959.

The work of the Mission de France did - and still does - provide an inspiration to underground priests in Czechoslovakia, who were familiar with its work and thinking, as well as that of the Jeunesse Ouvrière Chrétienne. ${ }^{96}$ They welcomed the insights which it brought to their own work, but differed on one key point - politics. Most of the French and Belgian worker-priests were or became militantly left wing, and chose to take work. In Czechoslovakia these priests were obliged to take a job. Priests who had lost their state licences had to take a manual job as window cleaners, tramdrivers or, that traditional dissident occupation, stokers. Undetected secret priests often had jobs with greater social prestige, such as engineers or medical personnel. While all rejected communism completely, most avoided politics and stuck strictly to religious activity.

Comparisons have also been made with the base communities which developed in Latin America and some European countries. Obvious similarities - such as the 
distance from traditional models of the priest and parish life, greater involvement of the laity and informality in worship - likewise masked a deep gulf with the Czechoslovak secret groups, again on the question of politics. Contacts with base group activists abroad were unhappy, with priests from Czechoslovakia uneasy about how far some base communities had travelled from their faith. Three representatives from the underground church were invited to one base group meeting in Paris in 1991, but were appalled - as were delegates from East Germany and Hungary - that there were no crosses and that one group paraded up and down with red flags, almost advertising their Marxism. ${ }^{97}$

Priests from the Zvěrina/Mádr circle, especially those in Prague or other Czech towns and cities, had, it seems, greater contact with non-Catholic Christians. Lectures and seminars organised in Prague in secret were often attended by both Catholics and Protestants, who shared ideas and experiences freely. 'We remember the lectures at the Protestant Theological Faculty', declares Tomás Halík of the Prague Spring era. The friendships established then between intellectuals from the Protestant and Catholic Churches continued in the more repressive era after 1969. Catholics attended the seminars of the Protestant Ladislav Hejdánek, while Protestants attended those of the Catholic Radim Palouš.

\section{The Underground Church and Politics}

Both sets of priests were of course strongly opposed to the communist regime, not just because of religious persecution and restriction, but on ideological or theological grounds. A certain number of priests (without state licences) became active in opposition circles. A few - such as the younger priests Václav Malý, Josef Kordík and František Lízna, as well as Josef Zvěrina from the older generation - were actively and openly involved in the Charter 77 movement, despite the initial bitter opposition of Cardinal Tomášek to it. The Charter itself called for the lifting of the restrictions on the churches and their clergy. This Catholic participation did much to forge links between the often secularised intellectual dissidents and the Catholic Church and helped it to shake off its backward-looking image.$^{98}$ Catholic lay people played a greater role than priests.

The church's ban on priests standing for elected political office, as well as its belief that lay people alone should be involved in directly political action, may have dissuaded other priests from coming forward openly. Indeed, it is a matter of pride to the Czech Brethren that fully 10 per cent of their pastors came forward to sign the Charter, despite the problems they knew would ensue.

Priests in Davidek's and other underground circles had to be more cautious about getting into trouble over unnecessary non-religious activity. But Davídek and others are known to have supported political opposition to the communist regime, although there was also a group within that part of the church which preferred to steer clear of politics altogether to concentrate on religious work. Davídek and the layman Dr Miroslav Richter are reported to have discussed greater cooperation with Charter 77 in 1988, shortly before Davidek's death and the fall of the communist regime. ${ }^{99}$

Davidek had always been suspicious of communist liberalisation and, just as he had underestimated the reforms of the Prague Spring and - correctly - believed it could not last, so he believed Gorbachev's glasnost' and perestroika were a sham. His late support for Charter 77 was, perhaps, a belated realisation that political change came not so much from the communists giving citizens more power, but from people seizing power for themselves. 
Support for Charter 77 did not mean that this sector of the church was conservative in a political sense. Many priests and lay people had, despite the difficulties of obtaining texts, studied Catholic social thought, often in the form of papal encyclicals, and tried to disseminate Vatican teaching. Such political activity would have been easier for the Czechoslovak state to condemn had it been of a truly reactionary character. Indeed it was often the priests working with state licences who had more conservative political views.

\section{The Official Priesthood}

Only priests with state licences were allowed to work openly during the communist era. These licences could be granted or revoked at will, and the number at any one time acted as a barometer of church-state tension. In the run-up to the Prague Spring of 1968 a greater number were issued, even to those who had previously been banned and to secret bishops like Otčenášek and Korec (although only to work as parish priests). Whether a priest had been ordained with government approval did not always make any difference. Those who completed the officially approved seminaries, such as Fr Václav Malý and Fr František Lízna, were deprived of state licences on occasion.

Official priests were under the close supervision of the government's State Secretariat for Church Affairs, which paid their salaries. Priests had to report frequently to their local commissioner, and failure to attend or supply information demanded could result in loss of the licence. A priest in Košice reported in 1989 that he was the only one in his area to refuse to attend meetings organised by the local commissioner. ${ }^{100}$ Priests would also be visited by members of the $\check{\text { StB }}$ and asked to collaborate. An estimated third to a half received such visits, ${ }^{101}$ and about 11.5 per cent were revealed to have collaborated. With such tight restrictions on the priest's activity and the constant threats from the authorities it is not surprising that only a few priests chose to defy restrictions completely.

Catholic activist Dr Václav Benda described the results of this in 1979:

The priesthood is to a great extent politically and culturally isolated: a significant portion of the ordinary clergy (though here the situation is incomparably better than among the hierarchy) are to some degree 'entangled' with the state, and in most cases all effective solidarity between the parishioners and their priest is entirely lacking. ${ }^{101}$

He believed that 'those who have survived long terms of imprisonment are old and, with certain honourable exceptions, they are weary and sceptical (though hardly any of them are actually broken).' Benda contrasts Catholic priests unfavourably with Protestant pastors, who were apparently bolder at defying state pressures.

Timidity on the part of official priests was one of the main complaints of the underground church, especially - although not exclusively - of Davídek's group. After the 1989 revolution it was seen more widely as a problem in the of ficial church. 'The state of the clergy is unsatisfactory', said Fr Tomás Halik in 1990. 'There are too few priests and many are old and exhausted. An "inner censor" inside them automatically stops any initiative. They have got used to manipulation by the state and many of them are helpless in the face of freedom.' This was precisely the result the communist regime aimed for. The church's role was to be narrowly circumscribed: 'People outside the church, as well as Catholics themselves and even some priests, forgot that Christian work in education, culture, public life and the charitable sphere is an integral part of the church's life.' ${ }^{103}$ 


\section{The Underground Church in the Church-State Conflict}

The state kept close tabs on the underground consecrations from the time of the Vatican's early attempts to organise a clandestine hierarchy. In a remarkably short time it seems to have discovered all the secret consecrations, both then and in the case of the later consecrations in the Davidek circles. The state appears to have been quite familiar with the conflict between the Vatican and Davidek's unapproved consecrations and ordinations. It was soon aware that Davidek had decided to evade detection by ordaining married men to the priesthood. It sent agents masquerading as secretly ordained clergy both within the country and abroad to find out more about the underground church and who was involved in it.

Some believe that the fact that Davidek and his colleagues were not impeded in their work by the secret police indicates that they were collaborators with the StB or, at least, unwitting agents. Stehle believes that while Davidek knew the ŠtB were on to him, he believed - wrongly - that he was cleverer than they and could outwit them. ${ }^{104}$ The spokesman for the Slovak bishops' conference, Fr Fridolin Hlinka, speaking in 1991, described Davídek's followers as 'a fifth column under the protection of the StB'. The bishops and priests, 'even in the time of the harshest persecution', signed their letters with 'crosses and emblems', a sure way, Hlinka believed, for them to reveal their true roles. ${ }^{105}$

Behind the scenes, the communist regime seems to have been aware of the potential for embarrassment to the church of the inner conflict between the different branches of the underground church. During talks with the Vatican the Czechoslovak side used the conflict to try to gain advantage, knowing the Vatican would try to keep the dispute behind the scenes. However, the surprising element of the whole story is that the $\breve{S t B}$ and the communist press did not make more of the conflict in public to embarrass the church on what they knew was a highly sensitive subject. It seems they did not want to encourage further anti-state activity by revealing publicly the extent of unauthorised and uncontrolled religious work. It seems that only in the case of Zahradník and his two colleagues did the state intervene, and even then did not exploit the case to the full by trying to highlight the divisions within the church. By the 1980s, when the three were arrested, communist states were already wary of the ill effects on world opinion of visible religious persecution and sought, wherever possible, to avoid arrests or, if these were absolutely necessary, to arrange sentences based on criminal charges unrelated to religious activity.

This decision not to exploit the division did not prevent a vigorous and often virulent press campaign against 'the underground church'. Numerous waves of articles appeared, especially in Slovakia, attacking priests and lay Catholics involved in illegal activities. ${ }^{106}$ Attacks focused on production and distribution of religious literature, work by the secret religious orders and mass pilgrimages. However, these articles, while revealing extensive knowledge of active individuals, treated the underground church as one whole, and did not reveal or seek to exploit divisions between the Vatican-loyal and Davidek-loyal groups. Instead, the press tried to foment conflict between the underground church and the legal church 'above ground', which existed with state approval and under state control.

The communist state also tried to put pressure on the Vatican to condemn the 'secret church'. A 1981 Catholic samizdat report emphasised the state's concern: 'An even clearer indication of this anxiety was the demand made by representatives of the Czechoslovak government at their meeting with the Holy See, that the Vatican and the Czechoslovak bishops should themselves take steps against the "secret church".,107 
For its part the Catholic Church repeatedly addressed the question of the 'underground church', but without admitting any splits within it, insisting that the underground and legal church formed a unified whole. An extensive 1981 article in the samizdat journal Informace o církvi ${ }^{108}$ described and discussed the 'secret' church without once hinting at any possible divisions. In a 1986 interview with the Austrian newsletter $I D L$, Bishop Ján Korec attacked attempts to divide the Slovak church into 'legal' and 'underground' parts. 'There is only one Church', he declared categorically. 'There is likewise only one priesthood.' 109 A close collaborator of Korec, Ján Čarnogurský, declared:

Activists of an underground pastoral ministry reject the Iabel 'secret church', however, emphasising that the church is one and performs a single mission.... The underground church is not a distinct part of the Catholic Church; the label is simply a convenient term for such religious activity as the regime forbids, and for those people who take part in it. ${ }^{110}$

Such sentiments were frequently echoed by Cardinal Tomášek. They were repeated by Pope John Paul II in Prague in 1990, who stressed the unity of the church.

It is interesting that the Czechoslovak communist authorities took a different attitude to the underground parts of legal churches from the Soviet authorities. ${ }^{11}$ As we have seen, the Latin Rite Catholic Church in Belorussia and elsewhere made use of ordination in secret by officially approved bishops, or ordination abroad. However, these priests were not by nature ineligible to work as parish priests with official approval, despite the difficulty some had in gaining acceptance from the Soviet Council for Religious Affairs. ${ }^{112}$ Likewise, certain bishops of the Russian Orthodox Church ordained men to the priesthood who had not completed the officially approved seminaries in Moscow, Leningrad or Odessa. Although the CRA complained of such ordinations - a secret 1970 report attacked Metropolitan Palladi of Orel for this ${ }^{113}$ - it did not usually block subsequent acceptance as parish priests. In addition, there are numerous cases of priests being dismissed at the instigation of the CRA or KGB for being too zealous who subsequently managed to gain work as priests in other dioceses. ${ }^{114}$ Such 'liberality' would have been unthinkable in Czechoslovakia. No priests ordained in secret are known to have been given a state licence, and few whose state licences were revoked received them back within a short space of time - if at all.

\section{Reintegrating the Church}

It is clear that no part of the church foresaw the difficulties and bitterness of reintegrating the different parts of the church, despite the concern there already was in the Vatican about the secret ordinations by Davídek and others. Even beyond Pope John Paul's triumphal visit to the country in April 1990 - unimaginable six months before - the question had barely been raised. Both then and later it seemed the Vatican had no clearly thought-out policy on an issue they knew would eventually arise.

The two Vatican-approved secret bishops (Otčenášek and Korec) were immediately reintegrated into the hierarchy when the Pope made his first appointments to fill the many vacant dioceses. In 1990 Otčenášek was installed as Bishop of Hradec Králové (he had been listed for some years in the Vatican yearbook as diocesan bishop with the comment 'impedito'), Korec as Bishop of Nitra. (The government had allowed Tomášek to be appointed to Prague in 1965, Matoušek in 1988.) While there was no 
doubt about the good standing of these candidates, the Vatican took longer to reach a decision about Bishop Peter Dubovský. He was appointed as auxiliary bishop of Banská Bystrica only in January 1991, some time after the reestablishment of the hierarchy. This indicates a certain initial doubt on the part of the Vatican that his consecration was valid.

The Vatican doubtless hoped that with Dubovský's appointment the question of secret consecrations would be solved. Of the nine bishops consecrated in secret up to Dubovský, two had died (Štefan Barnáš in 1964 and Ladislav Hlad in 1979), two had emigrated (Hnilica and Kal'ata) and five were now in office (Matoušek, Tomášek, Otčenášek, Korec and Dubovský).

Behind the scenes, though, the scale of the problem was emerging. Two secretly consecrated bishops, Jan Bláha (living as an unemployed chemist in Brno) and Stanislav Krátký (working as parish priest in Hrádek), visited Rome in spring 1991 in separate attempts to have their status recognised. Blaha was apparently - after some delay - given a meeting with the head of the Congregation for the Doctrine of the Faith, Cardinal Ratzinger, but in the end both returned empty handed. ${ }^{115}$ The Congregation had already decided to handle the matter itself, rather than leave it to the local church. It had ordered secret priests to report in to their local bishops by August 1990, and had directed that these bishops should send the lists of secret clergy - bishops and priests - to the Congregation in Rome for adjudication. Not all secret clergy reported in.

It was in 1991 that the hidden tensions came to the surface, exacerbated by the publication of sensationalist articles in the Austrian press and, late in 1991, by the publication in Austria of Gansrigler's book - widely read throughout the church in Czechoslovakia. One of the first public Vatican statements on the question of secret ordinations was the admission, after Archbishop Vlk's revelation that women had been ordained and mounting speculation in the foreign press, by spokesman Dr Joaquín Navarro-Valls that two women had been ordained under the communist regime. Official Catholic sources within Czechoslovakia had, up to then, been extremely reluctant to recognise in public that a problem even existed, and considered anyone investigating the issue to be acting against the church. The subject was very sensitive and the church in Czechoslovakia was unused to an investigative press treating church affairs as a legitimate subject of journalistic enquiry. In some ways this issue succeeded in opening up the church to journalists, and to allow a more public, lay-led discussion of church affairs. By now the question was on the open agenda.

On 8 March 1992 the Czechoslovak bishops' conference addressed a letter to all secret clergy, asking them to come forward and report to their local bishop by Palm Sunday, 12 April. 'Whoever wishes to remain a "secret" priest after this date', the letter said, 'must recognise that he is not undertaking any apostolate for the church, but in fact damages it and excludes himself from its community.'

This deadline was apparently set by Cardinal Ratzinger, whose Congregation was handling the question, and had already received files of every single case of those who had reported in. The final list, compiled - 'after diligent research'116 - by the Congregation with the help of the Czech and Slovak bishops, contained the names of 17 bishops and 200 priests. All were men. No women ordained in secret, including the two who visited Cardinal Tomášek in the 1980s, came forward, implying that if they were still alive they did not consider themselves to be priests. Nevertheless, the bishops were instructed that if any woman came forward, they were to make it clear that any such ordination is null and invalid as Catholic doctrine does not allow for the 
possibility of women's ordination.

Most of the secret groups collaborated with the local bishops in compiling lists of 'their' clergy. Bláha and Krátký (the latter reluctantly) put together a list and sent it to Rome. ${ }^{117}$

The Congregation divided the bishops into those who had been validly ordained as priests - that is with Vatican approval - and those, such as Zahradník, whose priestly ordination was in doubt. Of the 17 bishops, four were married. Of these four married bishops, two signed a declaration renouncing the exercise of episcopal ministry. Decisions on the other two, who did not renounce their episcopal ministry, were left to the local bishops, who were empowered, if they considered it appropriate, to give them conditional ordination as priests.

Eleven, whose priestly ordination was accepted, would be asked to renounce the exercise of their episcopal ministry, but could remain in their current ministry (eight of the eleven were already parish priests and one was superior of a religious order). Decisions on the other two of the eleven, who were not engaged in pastoral work apparently because of age and health, were left to the local bishops.

Doubts about the validity of the consecrations of some of these bishops therefore put in doubt the ordinations of priests they had conducted. Local bishops were empowered to reordain sub conditione those they considered suitable. In the case of Latin Rite priests, they would have to be celibate. Only in the Eastern Rite (and its biritual priests) would married priests be eligible for conditional reordination. The question of celibacy seemed to override other considerations, such as the theological knowledge of those involved or their suitability for integration into a diocesan structure which they were unused to. This reflected the preoccupation of Pope John Paul II with retaining a celibate priesthood in the western church against widespread calls for its abandonment.

To overcome the difficulties of reintegration of such priests, arrangements were made to start supplementary theological training. In addition, diocesan clergy days were arranged to bring priests of the different backgrounds together and to integrate them into a functioning community.

The text of the March letter, read out in all Czechoslovak churches, was approved at the 19 February meeting of the Czechoslovak bishops' conference, where the whole question of the secretly ordained priests and bishops was discussed. ${ }^{118}$

Ratzinger's concern was shown by the amount of time taken up on the question during his long-projected visit to Czechoslovakia from 28 March to 1 April 1992. He brought with him from Rome a document to the church leadership setting out guidelines on the question, a document which was not published and which, according to church spokesmen, will remain confidential. ${ }^{119}$ The Cardinal had already - at the beginning of 1992 - written to the heads of all Eastern European dioceses, asking for full lists of all secretly ordained clergy.

As part of the Vatican's usual procedure of informing leaders of the church throughout the world, the Secretariat of State (presumably with information supplied by the Congregation) also wrote a report which was sent in mid-1992 to all papal nuncios and apostolic delegates for the purpose of putting the Congregation's view of the problem to the local hierarchies. This document too was not for publication.

The Pope has repeatedly stressed the need for unity and loyalty in the church. This was a key theme of his address to the Czech and Slovak bishops who came to Rome in June 1992 for their ad limina visit, the first time a complete episcopate had been able to visit the Vatican for $\mathbf{4 0}$ years. Despite 'wonderful bright spots' in the church in Czechoslovakia, the Pope recognised that 'at the same time, shadows are not 
doubt about the good standing of these candidates, the Vatican took longer to reach a decision about Bishop Peter Dubovský. He was appointed as auxiliary bishop of Banská Bystrica only in January 1991, some time after the reestablishment of the hierarchy. This indicates a certain initial doubt on the part of the Vatican that his consecration was valid.

The Vatican doubtless hoped that with Dubovský's appointment the question of secret consecrations would be solved. Of the nine bishops consecrated in secret up to Dubovský, two had died (Štefan Barnáš in 1964 and Ladislav Hlad in 1979), two had emigrated (Hnilica and Kal'ata) and five were now in office (Matoušek, Tomášek, Otčenášek, Korec and Dubovský).

Behind the scenes, though, the scale of the problem was emerging. Two secretly consecrated bishops, Jan Bláha (living as an unemployed chemist in Brno) and Stanislav Krátký (working as parish priest in Hrádek), visited Rome in spring 1991 in separate attempts to have their status recognised. Blaha was apparently - after some delay - given a meeting with the head of the Congregation for the Doctrine of the Faith, Cardinal Ratzinger, but in the end both returned empty handed. 115 The Congregation had already decided to handle the matter itself, rather than leave it to the local church. It had ordered secret priests to report in to their local bishops by August 1990, and had directed that these bishops should send the lists of secret clergy - bishops and priests - to the Congregation in Rome for adjudication. Not all secret clergy reported in.

It was in 1991 that the hidden tensions came to the surface, exacerbated by the publication of sensationalist articles in the Austrian press and, late in 1991, by the publication in Austria of Gansrigler's book - widely read throughout the church in Czechoslovakia. One of the first public Vatican statements on the question of secret ordinations was the admission, after Archbishop Vlk's revelation that women had been ordained and mounting speculation in the foreign press, by spokesman Dr Joaquín Navarro-Valls that two women had been ordained under the communist regime. Official Catholic sources within Czechoslovakia had, up to then, been extremely reluctant to recognise in public that a problem even existed, and considered anyone investigating the issue to be acting against the church. The subject was very sensitive and the church in Czechoslovakia was unused to an investigative press treating church affairs as a legitimate subject of journalistic enquiry. In some ways this issue succeeded in opening up the church to journalists, and to allow a more public, lay-led discussion of church affairs. By now the question was on the open agenda.

On 8 March 1992 the Czechoslovak bishops' conference addressed a letter to all secret clergy, asking them to come forward and report to their local bishop by Palm Sunday, 12 April. "Whoever wishes to remain a "secret" priest after this date', the letter said, 'must recognise that he is not undertaking any apostolate for the church, but in fact damages it and excludes himself from its community.'

This deadline was apparently set by Cardinal Ratzinger, whose Congregation was handling the question, and had already received files of every single case of those who had reported in. The final list, compiled - 'after diligent research'116 - by the Congregation with the help of the Czech and Slovak bishops, contained the names of 17 bishops and 200 priests. All were men. No women ordained in secret, including the two who visited Cardinal Tomášek in the 1980 s, came forward, implying that if they were still alive they did not consider themselves to be priests. Nevertheless, the bishops were instructed that if any woman came forward, they were to make it clear that any such ordination is null and invalid as Catholic doctrine does not allow for the 
possibility of women's ordination.

Most of the secret groups collaborated with the local bishops in compiling lists of 'their' clergy. Bláha and Krátký (the latter reluctantly) put together a list and sent it to Rome. ${ }^{117}$

The Congregation divided the bishops into those who had been validly ordained as priests - that is with Vatican approval - and those, such as Zahradnik, whose priestly ordination was in doubt. Of the 17 bishops, four were married. Of these four married bishops, two signed a declaration renouncing the exercise of episcopal ministry. Decisions on the other two, who did not renounce their episcopal ministry, were left to the local bishops, who were empowered, if they considered it appropriate, to give them conditional ordination as priests.

Eleven, whose priestly ordination was accepted, would be asked to renounce the exercise of their episcopal ministry, but could remain in their current ministry (eight of the eleven were already parish priests and one was superior of a religious order). Decisions on the other two of the eleven, who were not engaged in pastoral work apparently because of age and health, were left to the local bishops.

Doubts about the validity of the consecrations of some of these bishops therefore put in doubt the ordinations of priests they had conducted. Local bishops were empowered to reordain sub conditione those they considered suitable. In the case of Latin Rite priests, they would have to be celibate. Only in the Eastern Rite (and its biritual priests) would married priests be eligible for conditional reordination. The question of celibacy seemed to override other considerations, such as the theological knowledge of those involved or their suitability for integration into a diocesan structure which they were unused to. This reflected the preoccupation of Pope John Paul II with retaining a celibate priesthood in the western church against widespread calls for its abandonment.

To overcome the difficulties of reintegration of such priests, arrangements were made to start supplementary theological training. In addition, diocesan clergy days were arranged to bring priests of the different backgrounds together and to integrate them into a functioning community.

The text of the March letter, read out in all Czechoslovak churches, was approved at the 19 February meeting of the Czechoslovak bishops' conference, where the whole question of the secretly ordained priests and bishops was discussed. ${ }^{118}$

Ratzinger's concern was shown by the amount of time taken up on the question during his long-projected visit to Czechoslovakia from 28 March to 1 April 1992. He brought with him from Rome a document to the church leadership setting out guidelines on the question, a document which was not published and which, according to church spokesmen, will remain confidential. ${ }^{119}$ The Cardinal had already - at the beginning of 1992 - written to the heads of all Eastern European dioceses, asking for full lists of all secretly ordained clergy.

As part of the Vatican's usual procedure of informing leaders of the church throughout the world, the Secretariat of State (presumably with information supplied by the Congregation) also wrote a report which was sent in mid-1992 to all papal nuncios and apostolic delegates for the purpose of putting the Congregation's view of the problem to the local hierarchies. This document too was not for publication.

The Pope has repeatedly stressed the need for unity and loyalty in the church. This was a key theme of his address to the Czech and Slovak bishops who came to Rome in June 1992 for their ad limina visit, the first time a complete episcopate had been able to visit the Vatican for $\mathbf{4 0}$ years. Despite 'wonderful bright spots' in the church in Czechoslovakia, the Pope recognised that 'at the same time, shadows are not 
lacking'. Priests 'have not had the opportunity for theological and pastoral updating, such as in the [Second Vatican] Council documents,' the Pope declared, and 'a certain sense of individualism has taken over.' He repeated the wish that 'the painful divisions created in the ranks of the clergy who worked with organisations that were sympathetic to the [communist] regime can be overcome.' He declared the

firm hope that the ecclesiastics who were secretly ordained - whose cases have been studied individually and with great attention by the dicastery charged with that task [i.e. the Congregation for the Doctrine of the Faith] - may accept the solutions offered and, for the good of the Church, place themselves at the disposal of their legitimate Pastors, you the Bishops. I invite them to do so, with great fraternal affection, moved by the witness which they have given. The 'great harvest' awaits them! ${ }^{120}$

Thus the Pope echoed the letter of the Czech bishops the previous March.

In its attempt to regularise the situation according to Canon Law, the Vatican looked not just at the most visible sacrament of the underground church - ordination of priests and bishops - but at the sacraments the secret clergy administered. Baptism presented no problem, as anyone may baptise. There was nothing the Vatican could do about the many Masses said, but marriages conducted by underground priests had to be tackled. The Congregation for the Doctrine of the Faith decided to grant a sanatio in radice to those who were married by priests whose ordination was doubtful, in effect a retrospective decree that their marriages had been valid from the start. There was no need for couples to apply individually.

Just before Ratzinger's March visit, it was reported that the first acceptance of a Davídek bishop had taken place. Dušan Špiner, secretly consecrated by Davídek on 6 October 1979, was apparently seen as his successor. The church was reported to have accorded Špiner (who had been involved in the Russian ordinations) the personal rank of bishop, but he was not given episcopal duties, remaining parish priest in Nová L'ubovna in the Slovak diocese of Spiš. Commentators pointed to the fact that Špiner was not married and had been consecrated by Davídek before his 1983 fall which, according to official church sources, had affected his brain. ${ }^{121}$ Špiner had studied in the Bratislava seminary and had been ordained openly in 1973 by Bishop Július Gábriš, apostolic administrator of the Trnava Archdiocese. However, the report of Špiner's acceptance was denied by Bishop František Tondra of Spiš. ${ }^{122}$

Interestingly enough, the two secret bishops of the Eastern Rite in Slovakia, who had loyally accepted the Vatican's decision not to recognise their episcopal status, received support from the Ukrainian Catholic bishop of Przemyśl, Ivan Martynyak. He raised the question of their recognition at the May 1992 synod of the Ukrainian Catholic bishops in L'viv, which - on his intervention - discussed their cases as well as those of three bishops consecrated without Vatican approval after tensions between Cardinal Slipyi and Pope Paul VI. ${ }^{123}$ The two, working as parish priests in Slovakia, have not had their episcopal status recognised. Bishop Ján Hirka of Prešov describes them as having freely given up their episcopal office. ${ }^{124}$

Reintegrating other priests and bishops - especially those who were married - was not so easy. Married clergy were offered possible work as married deacons or as priests in the Eastern Rite in Slovakia. Most have spurned this offer. Gansrigler reports that Prešov's Eastern Rite bishop Ján Hirka also refused to accept such a large number of former underground priests, most of them Czech. ${ }^{125}$. However, in 1992 he did begin to accept some, apparently under strong Vatican pressure. These would 
come under his jurisdiction, but would work as biritual priests mostly in the Latin Rite.

Many secret priests and bishops, most prominently Bishop Zahradník, refused to accept the terms offered by the church and continued with and even developed their ministry, sometimes cooperating with the official clergy. Zahradnik, who became director of social services in his home town of Rychnov nad Kněžou after the fall of the communist regime, has been instrumental in projects to help local gypsies driven out of Slovakia and Czech refugees who left Ukraine after the Chernobyl' disaster. He sees this as his new ministry, a ministry not being taken on by the rest of the church. 'We are filling in the gaps in the official pastoral care, in the places where the official priests could not go, and today cannot or do not want to go, or do not want to go yet. ${ }^{126} \mathrm{He}$ is also continuing the task of rebuilding ruined churches which he began during his enforced employment as a builder in the communist era.

Other secret priests are continuing the work with their own groups, apparently at their request. ${ }^{127}$ Most of these priests have reported in to their local bishops, whose level of sympathy for the secret clergy varied widely. There were a few who, knowing they were unlikely to be accepted as priests or having little respect for their diocesan bishop, have not done so. (By August 1992, Fiala estimated, only about 40 per cent of all the secret clergy had reported in. ${ }^{128}$ ). Apart from administering the sacraments, they tend to concentrate on a particular group of Catholics, such as young people, and continue to organise retreats and outings. Although they claim to have no desire for rank - they do not suffer from what one priest described as 'acute mitre-itis'129 they wish to be able to continue this work officially. Most seem to be respecting the church's request (or order) that the details of their secret ordinations and negotiations with the hierarchy should not be made public or discussed in public.

The secret married clergy have gained the sympathy of Protestants, notably those of the Evangelical Church of Czech Brethren. Their different tradition on the role of the clergy makes it hard for them to look at the question from the same theological perspective as the Catholics. Some Catholics in Austria, Germany and North America have seized on the married clergy to advance their demands for a universal married clergy, thus sharpening the conflict between the Vatican and the married priests concerned. The Vatican does not want to set a precedent in the way it resolves these cases.

Church spokesmen insist that Canon Law must be upheld. Fr Fiala declares that there is no reason to make an exception to the rule on celibacy, as for example has been the case in the United States with convert Presbyterian or Episcopalian clergy or in Britain with convert Anglicans. He does not believe that the 'abnormal' situation of the church before 1989 merits an exception now that the church situation is, as he describes it, 'normal'. 130

Fr Fiala also does not consider that the dire shortage of priests, especially in Bohemia and Moravia, warrants a weakening of church discipline, despite its critical nature. Many priests have to serve up to a dozen parishes, especially in country areas. 'The shortage of priests can be felt everywhere,' reports Václav Nèmec. 'Compared with the state of the clergy at the beginning of the twentieth century, the number of priests - almost throughout Bohemia - has fallen to one-tenth.' ${ }^{131}$ In 1992, there were only two ordinations of diocesan priests in the huge Prague archdiocese, a relic of the restrictions on seminary entry under the communists. Despite good vocations now, as church sources emphasise, it will take some years for these young men to work through their training. Meanwhile, there have been hints from Vlk and Fiala that a compromise might be reached whereby some of the secret bishops may be accorded 
personal episcopal rank without the power to exercise episcopal functions.

How much will the church change because of the experiences under persecution? As Gansrigler argues,

It is the view that now, when everything has become easier, the church must make use of the experiences of the communist era and bring them into church life: one cannot simply revert to the pre-conciliar church of the 1940s with its categorical and aggressive pastoral programme. The time of persecution enabled the church to gain a new approach to people which should continue to be used in the new freedom. ${ }^{132}$

While other secret priests from the Zvěrina/Mádr group, such as Fr Tomăs Halík, might endorse such a new approach, they would not interpret that as an endorsement of the continuing work of Zahradník and his colleagues outside the framework of the official church. The official clergy will have problems, as many have seen, keeping close to the people now they have stepped behind the pulpits of churches.

\section{Consequences}

The irreconcilability of the different viewpoints makes a solution acceptable to all hard to find. The church maintains that Canon Law must be upheld. Married priests cannot be accepted in the Latin Rite, and secret consecrations undertaken without the approval and against the wishes of the Vatican cannot be accepted. On the other hand the secret clergy believe their faithfulness and hard work during the years of persecution must be recognised.

The Vatican - from Pope John Paul II downwards - has been taking the whole question of the secret clergy very seriously, despite the fact that devising a policy to solve the problem has proved difficult. With an eye to the future, the Vatican is determined that the confusion shall not arise again. The 1983 Code of Canon Law permits, in cases where the diocesan bishop is 'impeded' from exercising his functions by imprisonment, government restrictions or similar reasons, the election of other clerics to administer the diocese without prior reference to Rome, although notification is required as soon as is physically possible. ${ }^{133}$ The administrator's powers do not appear to include the power to ordain priests or consecrate successors. Indeed, elsewhere the Code states explicitly: 'No bishop is permitted to consecrate anyone as bishop, unless it is first established that a pontifical mandate has been issued." 134 (The following Canon requires that two consecrating bishops assist the consecrator in normal circumstances.) This does not preclude consecration in secret without state approval - as still happens in China - but it does require prior authorisation from the Vatican.

The objection the official church has always had to these secret ordinations is not just the question of priestly celibacy - important as the question is - but of the exercise of authority within the church. There is some truth to Archbishop Vlk's accusation that the parallel church arose because 'a few somewhat exalted persons did not assess the situation correctly.' ${ }^{135}$ Davídek and others - like Lefèbvre - wilfully refused to accept orders from the Vatican and, in effect, set up their own schismatic group that was prepared to accept many, or most, Catholic teachings while still rejecting church authority. While some of this can be understood - the leadership given by vicars capitular appointed by the communist regime was less than edifying a hierarchical church based on a system of authority cannot accept this situation. Who was Davídek to set himself up as the final arbiter on questions of jurisdiction and 
doctrine? Why did he refuse to accept commands from the church leadership he professed to be following? His high-handed attitude, even when he was right, caused visible distress in the Vatican. This doubtless accounts for the complete ignoring of his 1988 March Analysis of the problems in the church.

This does not mean that all his tireless work - and that of the other secret clergy - was without significance. Davidek's energy, ideas and forward-looking enthusiasm were certainly in short supply in the early years of communist rule and, for all his faults, he did contribute to debate and renewal in the church in Czechoslovakia. The hundreds of secret priests served their own flocks, however small, with loyalty and dedication and kept a real faith alive during the years of persecution. It was certainly the impulse of the secret clergy without church permission which motivated the official church to begin its own programme of secret training and ordination. Davídek's clergy - both before and after 1989 - provided a model of dedication (involving reaching out to those left at the margins of society and those with no religious background at all) from which the official clergy have much to learn.

Thus the secret married clergy, who are unlikely to be readmitted to the church as priests, feel resentful that this ministry has not been recognised. They see their dreams of a new church, modelled on the better traditions of their 'ecclesia silentii', derided and shattered. They refuse to accept that what they see as narrow legalistic argument should bar them from their fruitful ministry.

During 1992 there were attempts by the two sides to come together and try to find common ground. The official church has recognised that there were collaborators within its own ranks, and that it did not always provide a worthy image of the church, an argument always put forward by the secret clergy. For their part, the secret clergy have begun to recognise the sensitivity of the question of reintegrating married clergy into a necessary hierarchical structure. They have shown a willingness to accept a specially adapted ministry, albeit one that accepts the validity of their priestly vocations. One of the leading 'rebels', Fridolin Zahradník, softened his previous position that he should be recognised as a full bishop. 'With the 1989 revolution my role as a bishop ceased. I stepped in where there were none, and now each diocese has a couple my task is over.'136

Despite these moves towards some reconciliation, there is a legacy of bitterness on both sides about the hostile, often insulting remarks made by spokesmen on both sides of the divide.

One disturbing aspect of the underground church is the high level of emigration among priests, typical of both the church-approved and unapproved camps. Davidek himself tried to escape, unsuccessfully, in 1950, although he had had plans to leave even before then. Newly-consecrated Bishop Hnilica fled the country, "to the displeasure of his superiors' according to Stehle, ${ }^{137}$ within months of being unmasked as a bishop. Gansrigler has numerous references to priests of the underground church who now live in Austria or Switzerland. If the needs of the people were so great, why did so many flee?

On a more positive note the underground church, of both sorts, did much to push the government to make greater concessions to the church, just as in Lithuania the establishment of a 'secret seminary' (which had church approval) in the 1980s pushed the Soviet authorities to expand the number of places in the only Lithuanian seminary in Kaunas. Especially in Slovakia, where the underground church was more closely linked with the official church (because of the almost complete absence of an open hierarchy), events sponsored by the underground church had a huge impact. Underground prayer and family groups, as well as the mass pilgrimages to shrines at 
Levoča and Šaštin, with up to half a million participants, maintained the church's power and influence. The powerful campaign around the petition for religious freedom in 1988 was a joint action of the underground church (with which the author Augustin Navrátil had strong links) and the official church in the person of Cardinal Tomášek.

Secret consecrations and ordinations caused problems in other ex-communist countries, although not to the same extent as in Czechoslovakia. After the fall of the Ceausescu regime in Romania and the lifting of the ban on the Eastern Rite church, not all the secretly consecrated bishops were accepted. Three of them, Iustin Paven, Emil Riti and Octavian Cristian, had been consecrated in the 1980s by Bishop Ioan Dragomir, and there was dispute as to whether he had authorisation for this. Cristian died in 1989, but the other two came forward as bishops when the ban was lifted. According to Alexandru Todea, Dragomir was already psychologically disturbed and had consecrated the three under the influence of a visionary named Ionela. Todea maintains that the Pope had conveyed the wish that only the last surviving bishop could consecrate a successor. All the bishops, including Dragomir, had apparently accepted this instruction. After Dragomir's 1985 death, the remaining bishops had discovered these extra consecrations and sent documentation to Rome - thus proving that contact with the Vatican was possible, even for an illegal church in a dictatorship as harsh as Ceaussescu's. Rome agreed with the view of Todea and the other bishops that the three should not exercise episcopal functions on pain of excommunication. ${ }^{138}$ The official bishops recognised by the Vatican had to issue an embarrassing statement in their 8 January 1990 declaration of their demands for restitution: 'There are two persons making claims [to episcopal rank]: Iustin Paven, who has appeared on television as Bishop of Maramures, but whom the Romanian Uniate Church cannot recognise; and Emil Riti from Cluj, whom the church likewise cannot recognise. This is an inner church problem.' ${ }^{139}$ There have been no reports of problems in the reintegration of priests.

In Ukraine ten officially recognised bishops came forward when the church was relegalised at the end of 1989 . These were soon confirmed in office by the Pope, ${ }^{140}$ although Volodymyr Sterniuk's rank of metropolitan was not accepted by the Vatican which pointedly described him only as archbishop and 'locum tenens' of Rome-based Cardinal Lubachivsky. There were known to be four other secretly consecrated bishops (all of whom were elderly) who kept their consecrations quiet at Vatican request and as they saw no need to exercise episcopal functions now the church had a properly constituted hierarchy. ${ }^{141}$

The Eastern Rite churches in Romania and Ukraine shared complete illegality and the acceptance of a married clergy, both of which helped avoid the problems that afflicted the church in Czechoslovakia. There is more doubt about the status of priests and bishops in the Russian Rite Catholic Church, which has always had a rather confused history and structure. In 1980 Ukrainian bishop Pavlo Vasylyk secretly ordained an Estonian married priest, Einar Laigna, whose activities in Tallinn were later to cause divisions in the tiny Estonian Catholic Church.

The single biggest illegal church in the world is the Vatican-loyal Catholic Church in China, which has maintained a parallel underground structure to the governmentloyal Catholic Patriotic Association. The latter denies the authority of the Pope and - like so many other breakaway groups ${ }^{142}$ - allows a married priesthood. In November 1989 - perhaps under Vatican pressure - the underground bishops held a secret meeting to found a bishops' conference. This may have been an attempt by the local church to provide a structure to avoid the problems that have arisen in 
Eastern Europe whereby bishops have acted unilaterally and created sects within the church. In any case, the government-loyal church has been concerned by the underground church which it is supposed to control. Interestingly, the CPA bishop of Shanghai, Aloysius Jin Luxian, foresaw problems of reintegration after an eventual reunion with the Vatican because the underground church had 'too many bishops', and priests who lacked proper theological training. ${ }^{143} \mathrm{He}$ did not mention the problems that the married clergy would have.

The Vatican is known to have been concerned about the growth of a church within a church in Czechoslovakia as far back as the late 1960s. The problems that have arisen, both before and after 1989, have made the Vatican more wary of allowing secret consecrations in future. The Czechoslovak developments have clearly influenced the Vatican's attitude to China, with the restrictions now lifted in Eastern Europe the last nation where secret consecrations and ordinations are the norm.

\section{Notes and References}

1 They were not, of course, the only ones to use this term. Among many others, Pope John Paul II, as Archbishop of Kraków, used it in a letter (now in the archives of the Ukrainian Catholic University in Rome) to Iosyf Slipyi in 1971.

2 Dr Franz Hummer, Bischöfe für den Untergrund (Herold Verlag, Vienna, 1981).

${ }^{3}$ Franz Gansrigler, Jeder war ein Papst: Geheimkirchen in Osteuropa (Otto Müller Verlag, Salzburg, 1991). The book is based on interviews with participants in the underground church - Gansrigler himself describes it as 'oral history'. Although it does contain mistakes and discrepancies, it is as accurate as the interviews Gansrigler was given.

4 Gansrigler, op. cit., p. 202.

5 ibid.

6 The press conference was held on 16 October 1991, and was reported the same day by Kathpress.

7 See The Tablet (London), 26 October 1991, p. 1327, which also mentions criticism from Austrian Cardinals König and Groer. For a critical review by a noted commentator on the church in Eastern Europe, Hansjakob Stehle, see Die Furche (Vienna), 31 October 1991.

8 Interview in Prague, June 1992.

9 I am grateful to all those who helped me with information for this article within Czechoslovakia and outside. Most are cited in the notes. Others wished to remain anonymous - itself a sign of the sensitivity of the whole subject. Most of the information both here and in publications quoted comes from oral sources, mainly from the participants, who often had only an approximate idea of the true facts. This accounts for numerous discrepancies and errors in the written sources, even apart from the desire to blend fact and fiction. Assistant Bishop of Prague František Radkovský admitted to journalists that not all facts about the underground ordinations can be checked and that even for the church authorities much remains unclear. Kathpress, 9 April 1992.

10 Hansjakob Stehle, Eastern Politics of the Vatican, 1917-1979 (Ohio University Press, Athens, OH, 1981), pp. 128ff. Cf. Walter J. Ciszek, With God in Russia (Peter Davies, London, 1965), pp. $6 \mathrm{ff}$.

" Graham Greene, The Lawless Roads (William Heinemann, London, 1939), Penguin edition, pp. 19-20.

12 The story of the secret ordinations in Russia has been told many times, most notabiy in Stehle, op. cit. and Antoine Wenger, Rome et Moscou, 1900-1950 (Desclée de Brouwer, Paris, 1987).

13 For his justification of his actions, see Marcel Lefèbvre, An Open Letter to Confused Catholics (Fowler Wright, Leominster, 1986), p. 147, where he argues that 'faith, truth and life' override Canon Law.

14 For details see Václav Vaško, Neumlčená, Kronika Katolické Církve v Československu po 
Druhé Světové Válce (Zvon, Prague, 1990), Vol. II, p. 111.

15 Stehle, op. cit., p. 273. Secret Bishop Stanislav Krátký confirmed this version of events to Gansrigler; op. cit., p. 68. Fr Leo Kuchar, a secretly-ordained priest who later emigrated to Austria, claimed to Gansrigler that Verolino left behind a document passing on these faculties, op. cit., p. 78.

16 Interview with Fr Miloslav Fiala, spokesman of the Czech bishops' conference, Prague, June 1992.

17 Stehle mentions the secret consecrations (op. cit., pp. 273-4) although he gets some of the dates and other details wrong.

18 Address to Aid to the Church in Need conference in Schönstatt, Germany, March 1990, included in The Catholic Church in Eastern Europe: Persecution, Freedom and Rebirth (Aid to the Church in Need, Königstein, 1990), p. 22. 1917 Code (then in force), canon 331. abroad posing as secret bishops consecrated by Davidek, implying they suspected his status by then; ibid., p. 60. It took them longer to discover who had consecrated him, as in 1976 they questioned Fr Vladimír Richter, then on a visit from Austria, about this point; ibid., p. 141 .

33 Stehle, op. cit., pp. 340-41. This comment, added for the 1981 English translation, was not in the original 1975 German edition, and followed in the aftermath of Fr Bukovsky's visit to Czechoslovakia. May 1992.

44 Lidové noviny (Prague), quoted in The Warsaw Voice, 31 May 1992.

45 Gansrigler, op. cit., p. 145.

46 ibid., p. 148.

47 Interview in Prague, June 1992. 
$$
\text { Spring 1982, pp. 40-2. }
$$$$
\text { 7V interview with Stefan Rybár, op. cit. }
$$$$
8 \text { Interview in Faith magazine, April 1992, p. } 16 .
$$

ibid., p. 125. her statements should be treated with caution. explain why Korec was the emissary.

Gansrigler, op. cit., p. 158. not available.

Gansrigler, op. cit., p. 88. circle of Vatican 'insiders'.

Interview with Stehle, who heard this from John Bukovsky.

Interview with Fr Fiala.

Gansrigler, op. cit., p. 99. centuries'; op. cit., p. 94.

ibid., p. 105. by Czechoslovak émigrés.

See Statement no. 725.

Gansrigler, op. cit., pp. 106-7.

ibid., p. 148.

ibid., p. 69.

ibid., pp. 127 and 107. television 5 July 1992. Cf. Gansrigler, op. cit., p. 104.

Telephone interview with Nikiforov, June 1992.

Gansrigler, op. cit., p. 135.

Gansrigler, op. cit., p. 106.

Burton Bollag, 'Clandestine priests in Czechoslovakia lose Vatican status', International Herald Tribune, 13 April 1992. In my view, Javorova is not a reliable witness and most of

František Mikloško, Nebudete ich móct' rozvrát'it': Z osudov Katolíckej Cirkvi na Slovensku v rokoch 1943-89 (Archa, Bratislava, 1991), p. 121. Mikloško also told Gansrigler the same story: op. cit., p. 158. Mikloško did not explain how the message reached Korec from Rome, as Korec did not visit Pope Paul VI until July 1969, not did he

Interview with Fr Fiala. Also mentioned by Archbishop Miloslav Vlk in interview with Italian paper Avvenire during ad limina visit to Rome July 1992. The text of the letter is

As recalled by Václav Vaško, interview in Prague, June 1992.

Gansrigler, op. cit., p. 19, where he claims that Davidek's reports were read by a small

According to Archbishop Vlk, Davídek had assured the Vatican he would stop secret ordinations, but had not kept his word: interview with $K N A, 28$ July 1992.

Krčméry publicly denied this at the Gansrigler press conference, adding that he had asked Hirka about this even before the Velvet Revolution. 'Hirka became angry and said that never in his life had he given such permission.' Kathpress, 16 October 1991.

Curiously, Zahradník refused to tell journalists at Gansrigler's press conference who had consecrated him, although this is given in the book on p. 96 . Gansrigler is wrong in describing Zahradnik as 'the first married bishop of a Uniate Catholic Church for

Gansrigler, op. cit., pp. 103ff (quoting Zahradník) and 153. František Provaznik mentions the campaign against Davídek and Zahradnik, blaming it on the ŠtB; ibid., p. 54.

See Keston News Service (KNS), no. 276, 28 May 1987, p. 2, where they were mistakenly described as 'Czech Franciscans'. In an initial press release, Keston College had described them as 'secretly-ordained priests', but this had immediately been denied to Keston College

Die Furche, quoted in The Tablet, 24 August 1991, pp. 1035-6.

Interview with Vatican official once based in Austria who did not wish to be named.

Interview with a seminarian from the same parish, July 1992.

Informationsdienst Osteuropäisches Christentum (Munich), 29 May 1992, p. 41.

Interview with Štefan Rybáŕ, Europe Express documentary programme, shown on British

or details of methods used, especially in Slovakia, see an article on the secret church in 
81 Lezov [S. L. ], 'Religioznoye vozrozhdeniye ili kapitulyatsiya?', Strana i mir (Munich), $12 / 1986$, p. 28. Lezov, in a decidedly hostile description of Nikiforov's work, does not mention a specifically Czechoslovak connection, but maintains: 'His activity, which included contacts with foreign Catholics, did not remain undetected by the KGB.'

82 Private information.

83 There was a rumour circulating in Prague early in 1983 that Soviet specialists in antireligious persecution had arrived in Czechoslovakia in autumn 1982 to share their experience. See Patrick Michel, Politics and Religion in Eastern Europe (Polity Press, Cambridge, 1991), p. 223.

84 N. Yakovlev, 'TsRU protiv SSSR: gospod' i bomba', Oktyabr' (Moscow), 2/1987, pp. 155-83 and 3/1987, pp. 136-70. The information on Nikiforov appears in the second part, pp. 154-7.

85 Gansrigler, op. cit., p. 189. The existence of secret bishops in Hungary was first mentioned by Kathpress in April 1991, which did not name the two, declaring only that they were priests in the Esztergom Archdiocese. Kathpress speculated that after their position had been regularised they could be appointed as auxiliary bishops of the archdiocese.

86 Korec ordained 120 priests - all members of religious orders - between 1951 and 1989 , at first apparently knowing only the codenames of those he had ordained. Interview in Kathpress, 8 September 1992.

87 Interview with Kathpress, 18 September 1992.

88 Hopko, a Ukrainian, was in conflict with Hirka, a Slovak, and was disappointed he was not appointed to head the newly restored diocese after relegalisation. Hopko may thus have desired to ensure a Ukrainian succession in the Prešov diocese.

89 Jonathan Luxmoore and Jolanta Babiuch, 'Truth prevails: the Catholic contribution to Czech thought and culture', Religion State \& Society, vol. 20, no. 1, 1992, p. 109. On Kolakovič and his work, see also Vaško, op. cit., vol. 1, pp. 95ff. On his influence on the Slovak underground church around Korec, see Mikloško, op. cit., passim, and Ján Čarnogurský, 'The underground church and pilgrimages in Slovakia', English translation in The Salisbury Review (London), June 1989, pp. 34-7.

103 Tomás Halík, 'Church and society in Czechoslovakia: the evangelisation of a postcommunist country', talk given to a conference in Ampleforth, England, August 1990, text in $R C L$, vol. 19, nos 1-2, 1991, pp. 53-7.

104 Telephone interview, October 1992.

105 At Gansrigler press conference.

106 See for example, Pravda (Bratislava), 29 December 1980, or Rudé právo (Prague) and Pravda, 11 and 12 February 1988.

107 Informace o cirkvi, op. cit., p. 42. 

harassment.

ibid. The journal was closely connected with the Zvěrina/Mádr circle. Quoted in KNS, no. 266, 8 January 1987, p. 14.

Carnogurský, op. cit.

Completely illegal churches, such as the Ukrainian Catholic or the True Orthodox, relied entirely on secret consecrations and ordinations, and their clerics received constant A typical case showing how such priests gained official registration is that of Belorussian priest Fr Anatoli Gei, ordained in Poland in 1978. (See KNS, no. 299, 28 April 1988, pp. 9-13; Arkhiv samizdata (Munich), 6209, p. 11). Only one Latin Rite Catholic priest ordained 'unofficially' is known to have been the subject of criminal charges in the Soviet Union in the 1970 s or 1980 s specifically for working as a priest: $\mathrm{Fr}$ Jonas Kastytis Matulionis of the Lithuanian archdiocese of Vilnius. He was sentenced in 1985 for being an 'imposter'.

113 Iz otcheta za 1970 g., p. 1, quoted in Dimitry Pospielovsky, The Russian Church under the Soviet Regime 1917-1982 (St Vladimir's Seminary Press, Crestwood, NY, 1982), p. 419.

114 See Jane Ellis, The Russian Orthodox Church: a Contemporary History (Croom Helm, London, 1986), pp. 90-3.

115 Gansrigler, op. cit., pp. 64-5, 79.

116 In the words of a Vatican source.

117 Gansrigler, op. cit., p. 63.

118 Osteuropäisches Christentum, 29 February 1992, p. 10.

119 Interview with Fr Fiala. Assistant Bishop František Radkovský told journalists in Prague the guidelines would be published when all individual cases have been resolved: Kathpress, 9 April 1992.

120 English text of ad limina address in L'Osservatore Romano, English weekly edition, 8 July 1992.

121 Kathpress, 26 March 1992.

122 Kathpress, 14 April 1992.

123 See Osteuropäisches Christentum, 29 May 1992, p. 6.

124 Kathpress, 18 September 1992.

125 Karl-Peter Schwarz adds that the Eastern Rite church will not accept them 'because in its view they are not children of the Eastern Church', interview with Archbishop Vlk, Die Presse (Vienna), 24 July 1991.

Gansrigler, op. cit., p. 100. Cf. Traynor, op. cit., Bollag, op. cit., Rybár interview with Zahradník, op. cit.

Interview with secret married priest in Czechoslovakia who did not wish to be named, June 1992. For the experiences of another secret married priest, Fr Jiři Kvapil of the Olomouc Archdiocese, see the interview given to Austrian television ORF, as reported in The Tablet, 23 January 1993, p. 104. Interview with the Swiss agency APIC, quoted in The Tablet, 22 August 1992, p. 1054.

Interview with Fr Fiala.

ibid.

Gansrigler, op. cit., p. 101.

Canon 413.

Canon 1013.

Interview with Archbishop Vlk, op. cit.

TV interview with Štefan Rybár, op. cit.

Stehle, op. cit., p. 274.

Interview by Diethild Treffert with Metropolitan Todea, Kathpress, 25 January 1990. For Riti's version of events, see Gansrigler, op. cit., p. 161.

German text of declaration published by $K N A, 24$ January 1990.

This was despite the fact that two of the bishops consecrated by Sofron Dmyterko in 1989 had been consecrated against the wishes of the Vatican and the rest of the hierarchy.

141 Private information. Cf. Gansrigler, op. cit., p. 194, where he puts the number of 
unrevealed secret bishops at three.

142 Bishop Škarvada, interview, op. cit., regarded the immediate abandonment of clerical celibacy by such groups as the Hussite Church (founded in Czechoslovakia after the establishment of the Czechoslovak Republic in 1918) as a symbol of revolt and an inevitable augury of decline. On breaking from Rome the Church of England also immediately allowed priests to marry, as did Martin Luther in Germany. A Catholic visitor to China in 1992 reported that the two married bishops and married priests of the CPA are not accepted by the faithful, who often walk out of Masses said by married priests (private information).

143 Églises d'Asie (Paris), 12 June 1992. 